\title{
Drug Screening of Potential Multiple Target Inhibitors for Estrogen Receptor- $\alpha$-positive Breast Cancer
}

\author{
YUN-HAO DAI ${ }^{1,2}$, GUAN-YU CHEN ${ }^{2}$, CHIH-HSIN TANG ${ }^{3,4,5}$, \\ WEI-CHIEN HUANG ${ }^{2,4,6,7}$, JUAN-CHENG YANG ${ }^{2 *}$ and YANG-CHANG WU $2,7,8^{*}$ \\ ${ }^{I}$ School of Pharmacy, China Medical University, Taichung, Taiwan, R.O.C.; \\ ${ }^{2}$ Chinese Medicine Research and Development Center, Center for Molecular Medicine, \\ China Medical University Hospital, China Medical University, Taichung, Taiwan, R.O.C.; \\ ${ }^{3}$ Department of Pharmacology, School of Medicine, China Medical University, Taichung, Taiwan, R.O.C.; \\ ${ }^{4}$ Chinese Medicine Research Center, Drug Development Center, China Medical University, Taichung, Taiwan, R.O.C.; \\ ${ }^{5}$ Department of Biotechnology, College of Medical and Health Science, Asia University, Taichung, Taiwan, R.O.C.; \\ ${ }^{6}$ Graduate Institute of Biomedical Sciences, China Medical University, Taichung, Taiwan, R.O.C.; \\ ${ }^{7}$ The Biotechnology Department, College of Medical and Health Science, Asia University, Taichung, Taiwan, R.O.C.; \\ ${ }^{8}$ Graduate Institute of Integrated Medicine, College of Chinese Medicine, \\ China Medical University, Taichung, Taiwan, R.O.C.
}

\begin{abstract}
Background/Aim: Estrogen receptor $\alpha(E R \alpha)$ antagonist is the most common treatment for ER $\alpha$-positive breast cancer. However, compensatory signaling contributes to resistance to ER $\alpha$ antagonists. Thus, to explore the potential agents for targeting compensatory signaling, we screened multiple target inhibitors for breast cancer treatment. Materials and Methods: We attempted to build a structurebased virtual screening model that can find potential compounds and assay the anticancer ability of these drugs by overall cell survival assay. The downstream compensatory phosphorylated signaling was measured by immunoblotting. Results: Hamamelitannin and glucocheirolin were hits for ER $\alpha$, phosphoinositide 3-kinase (PI3K), and KRAS protooncogene, GTPase (KRAS), which were active against estrogen and epidermal growth factor-triggered proliferation.
\end{abstract}

This article is freely accessible online.

*These Authors contributed equally to this study.

Correspondence to: Yang-Chang Wu, Ph.D., Graduate Institute of Integrated Medicine, College of Chinese Medicine, China Medical University, No. 91, Hsueh-Shih Road, Taichung, Taiwan 40402, R.O.C. Tel: +886 422057153, Fax: +886 422060248, e-mail: yachwu@mail.cmu.edu.tw and Juan-Cheng Yang, Ph.D., Chinese Medicine Research and Development Center, China Medical University Hospital, China Medical University, No. 2, Yude Rd., North Dist., Taichung City 404332, Taiwan R.O.C. Tel: +886 422057153, Fax: +886 422060248, e-mail: qq9113054@gmail.com

Key Words: Multiple inhibitors, $\mathrm{ER}^{+}$breast cancer, aminopterin.
Additionally, we select aminopterin as a hit for ERQ, PI3K, $K R A S$, and SRC proto-oncogene, non-receptor tyrosine kinase (SRC) with inhibitory activities toward AKT serine/threonine kinase 1 (AKT) and mitogen-activated protein kinase kinase (MEK) signaling. Conclusion: Our structure-based virtual screening model selected hamamelitannin, glucocheirolin, aminopterin, and pemetrexed as compounds that may act as potential inhibitors for improving endocrine therapies for breast cancer.

Breast cancer is the most common cancer in the world and is the second leading cause of death in women (1). Endocrine therapies are considered the standard-of-care for ER $\alpha$-positive breast cancer treatment (2). However, disease in almost $30 \%$ of such patients eventually becomes resistance to endocrine therapies $(3,4)$. This resistance may be due to the induction of compensatory signaling that negates the effects of anti-estrogens (5-11). Given these compensatory effects, recent studies found beneficial effects from the combination of inhibitors of compensatory signaling such as phosphoinositide 3-kinase (PI3K)/ mammalian target of rapamycin (mTOR) or cyclindependent kinases (12-16).

Virtual screening is increasingly being used for large-scale screening. Furthermore, virtual screening provides intuitive and effective model for rational drug discovery at a relatively low cost (17-19). Structure-based virtual screening is a kind of virtual screening that was developed following the completion of the Human Genome Project based on advances in structural biology, X-ray crystallography, and nuclear magnetic resonance spectroscopy, which in turn 
revealed druggable target proteins and structure-related detail of their interactions with small molecular agents $(20,21)$.

The activation of receptor tyrosine kinase (RTK) signaling has been associated with the induction of resistance to antiestrogens. To date, targeting the downstream targets of RTKs with specific small molecules had demonstrated benefits in treatment for patients suffering from breast cancer (22). PI3K-AKT serine/threonine kinase 1 (AKT) signaling plays an important role in regulating cell survival and proliferation in ER $\alpha$-positive breast cancer, and inhibition of downstream target mTOR has been validated as potential drug combinations for advanced breast cancer (23). Apart from PI3K-AKT-mTOR signaling, RAS-mediated mitogenactivated protein kinase kinase (MEK)-extracellular signalregulated kinase (ERK) signaling is critical for RTK activation (22), and accumulating evidence has revealed the important role of RAS-MEK-ERK activated mutation in breast cancer (24-26). Although specific inhibitors of PI3KAKT-mTOR or RAS-MEK-ERK signaling have been developed, multiple targets remain unexplored. Additionally, the proto-oncogene SRC plays a role in the resistance to endocrine therapies $(27,28)$, implying the value of a combinational approach targeting of ER $\alpha$ and SRC. Unfortunately, saracatinib, a dual kinase inhibitor of SRC and BCR-ABL, plus aromatase inhibitor did not improve the outcome in patients with advanced breast cancer (29). Similar results were also found for the combination of RTK inhibitors and aromatase inhibitor. Co-blockade of human epidermal growth factor receptors 1, 2, and 3 with RTK inhibitor AZD8931 and anastrozole did not show benefits for patients with advanced breast cancer (30). On the other hand, several inhibitors of downstream signaling nodes such as mTOR and CDK4/6 significantly improved on the combination of endocrine therapies in breast cancer $(15,31$, 32). It is intriguing to explore potential anticancer agents with inhibitory effects on PI3K-AKT-mTOR and RAS-MEKERK signaling.

In this study, we applied structure-based virtual screening to explore multiple inhibitors from an available compound library targeting $\mathrm{ER} \alpha, \mathrm{PI} 3 \mathrm{~K}, \mathrm{KRAS}$, and SRC protooncogene, non-receptor tyrosine kinase (SRC).

\section{Materials and Methods}

Database. Data regarding a total of 49,752 compounds were downloaded from the natural product databases of the Ambinter $(n=41,588)$, Selleck $(n=146)$, Natural products database of Universidad Estadual de Feria de Santana (UEFS) $(n=499)$, SPECS $(n=701)$, and Traditional Chinese Medicine database Taiwan $(n=6,818)$ and retrieved from the ZINC database (https://zinc.docking.org/, accessed on: 19 Jan 2012) (33) for virtual screening.

Preparation of protein structures. The structures of ER $\alpha$ (PDB ID: 3ERT) (34), PI3K (PDB ID: 3HHM) (35), KRAS (PDB ID: 3GFT)
(36), and SRC (PDB ID: 2H8H) (37) were obtained from the Protein Data Bank (https://www.rcsb.org/) (38). The co-crystal water molecules, cofactors, and ligands included in the protein structures were all removed using DS 3.5 Visualizer software (39). After removing these co-crystal substances, the atomic hydrogens and charges of each protein's structure were modified according to the CHARMm force field with the partial charge Momany-Rone method using DS 3.5 Visualizer software.

Structure-based virtual screening. To find multiple inhibitors of the target proteins ER $\alpha$, PI3K, KRAS, and SRC, we performed structure-based virtual screening through molecular docking calculations using GOLD 5.1 software (40-42). The binding site definition was set as follows. The binding site radius was set to 10 $\AA$ (default), and the centroid was defined as the center of the cocrystal ligand binding site (active site) of the protein. Subsequently, cavity detection calculations with the Ligsite algorithm (43) were performed to refine the docking space and expand the setting size to include associated residues, with the $(x, y, z)$ coordinates of the cavity centers of ER $\alpha, \mathrm{PI} 3 \mathrm{~K}, \mathrm{KRAS}$, and SRC being set at (31.41, $-0.22,22.75),(60.78,63.69,110.87),(70.72,97.03,52.77)$, and $(21.01,21.28,59.31)$, respectively. In addition, the radius of the cavity of ER $\alpha, \mathrm{PI} 3 \mathrm{~K}, \mathrm{KRAS}$, and SRC was set at $14.379 \AA$ \&, 15.829 $\AA$ A $13.795 \AA$, and $12.770 \AA$, respectively. Moreover, search efficiency of $30 \%$ (virtual screening parameter) with auto settings and the scoring function GoldScore were set by GOLD 5.1 software. The binding affinities of the inhibitors 4hydroxytamoxifen (a known ER $\alpha$ inhibitor) (44), NVP-BEZ235 (a known PI3K inhibitor) (45), salirasib (a known KRAS inhibitor) (46), and saracatinib (a known SRC inhibitor) (47) were also estimated by molecular docking calculations using GOLD 5.1 software in order to set one of the filters (that is, the binding affinities of the inhibitors) for the virtual screening. These were used to filter out the compounds with scores lower than the scores of the inhibitors. To do so, the structures of these inhibitors were prepared using ChemBioDraw Ultra 11.0 software (PerkinElmer Informatics, Waltham, MA, USA), with the 3D arrangements of the structures being constructed and optimized with MMFF94 force field minimization using ChemBio3D Ultra 11.0 software (PerkinElmer Informatics). The definitions of the binding sites and docking parameters were set as the same as setting in carrying out virtual screening. Subsequently, to intersect the docking results for $\mathrm{ER} \alpha, \mathrm{PI} 3 \mathrm{~K}, \mathrm{KRAS}$, and SRC, and in order to clearly show the docking results of multiple targets through the virtual screening, a $3 \mathrm{D}$ point chart was generated with a $3 \mathrm{D}$ point plot module using DS 3.5 Visualizer software.

Cell lines and reagents. Cell lines, except MCF-7 R, were purchased from the Food Industry Research and Development Institute (FIRDI, Hsinchu, Taiwan, ROC), MCF-7 R were kindly provided by Dr. YaoTsung Yeh (48). MCF-7 and MCF-7 R cells were cultured in Dulbecco's modified Eagle's medium nutrient mixture F-12 (Life Technologies Gibco, Carlsbad, CA, USA) with $10 \%$ fetal bovine serum (Life Technologies Gibco). T47D and BT474 cells were cultured in RPMI1640 (Gibco) with 10\% FBS. MDAMB-361 cells were cultured in L-15 (Sigma-Aldrich) with 20\% FBS. All of the culture media contained $1 \%$ penicillin-streptomycin $(\mathrm{P} / \mathrm{S} ; \mathrm{Gibco})$. Cells were incubated at $37^{\circ} \mathrm{C}$ in $5 \% \mathrm{CO}_{2}$. The following compounds were purchased from Sigma-Aldrich and were used: Alexidine dihydrochloride, $( \pm)$-amethopterin ,aminopterin, atranorin, 


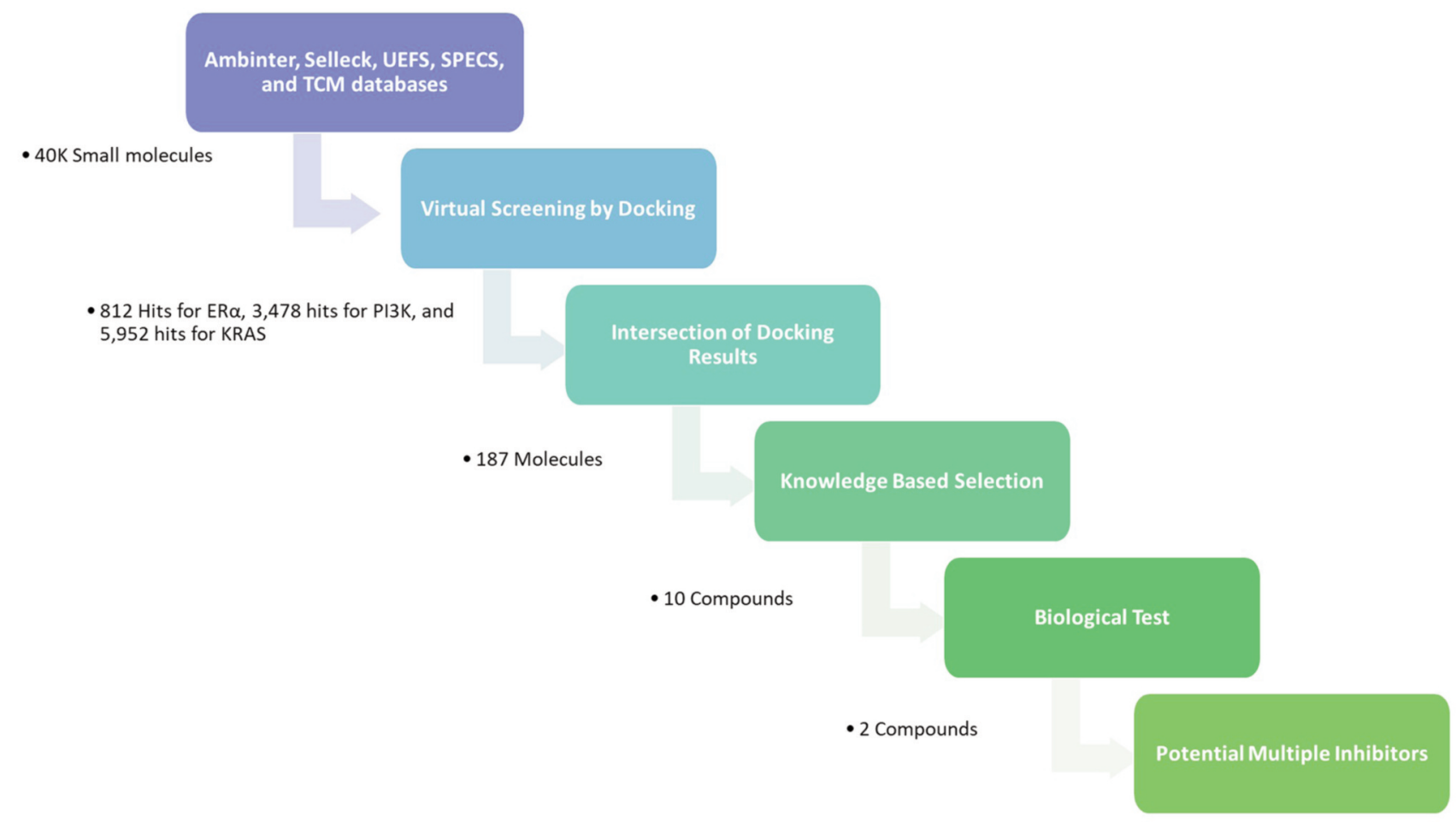

Figure 1. The flow chart of virtual screening targeting estrogen receptor alpha (ER $)$, phosphoinositide 3-kinase (PI3K) and KRAS proto-oncogene, GTPase (KRAS).

benfotiamine, benzthiazide, bucladesine, cefamandole sodium, cefmetazole sodium, cephalosporin C sodium, chlorhexidine dihydrochloride, curcumin, cytidine 5'-diphosphocholine sodium, 1,3dicaffeoylquinic acid, fumarprotocetraric acid, folic acid, glipizide, glucocheirolin, hamamelitannin, hyperoside, isochlorogenic acid $\mathrm{C}$, kaempferol 3-O-glucuronide, methotrexate, methyl prednisolone sodium succinate, mitoxantrone hydrochloride, nicardipine hydrochloride, pemetrexed, phthalylsulfathiazole, pyritinol, riboflavin 5-phosphate sodium, rottlerin, and sulfinpyrazone. The compounds were dissolved in dimethyl sulfoxide to a final concentration of 100 $\mathrm{mM}$ and stored at $-20^{\circ} \mathrm{C}$.

Survival assays. Assessments of cell viability were performed as follows. Cells were seeded in 96-well plates so that the control cells would reach approximately $80 \%$ confluency at the end of the assay. On the following day, the cells were treated for 5 days with increasing concentrations $(0$, $6.25,12.5,25,50$ and $100 \mu \mathrm{M})$ of the study drugs with/without stimulation for $30 \mathrm{~min}$ with $1 \mathrm{ng} / \mathrm{ml}$ epidermal growth factor (EGF) or $1 \mathrm{nM} 17$ beta-estradiol (E2). Treatment with each concentration was performed three times $(n=3)$. Cell viability was determined using the 3 (4,5-dimethylthiazol-2-yl)-2,5-diphenyltetrazolium bromide reagent as previously described (49-51).

Immunoblotting. Cell lysates were prepared as previously described (52). Antibodies against p-AKT (Ser473), AKT, p-p42/44 ERK (Thr202/Tyr204), p42/44 ERK, MEK $1 / 2$ and p-MEK1/2 (Ser217/221) were obtained from Cell Signaling Technology (Danvers, MA, USA). Equal amounts of protein were separated by $10 \%$ TrisGlycine Gel and then transferred onto polyvinylidene difluoride (PerkinElmer, Boston, MA, USA) membrane using Wet/Tank Blotting Systems (BIO-RAD, Hercules, CA, USA). The membrane was blocked with 5\% nonfat dried skimmed milk powder (Cell Signaling Technology) and incubated with primary antibody at a ratio of 1:1,000 overnight and washed with double-distilled water three times $10 \mathrm{~min}$ each. Then the membrane was incubated with goat anti-mouse or anti-rabbit horseradish peroxidase (HRP)conjugated secondary antibody (Santa Cruz Biotechnology, Dallas, TX, USA) and protein signals were developed with WesternBright ECL HRP substrate (Advansta, San Jose, CA, USA) then detected by ChemiDoc XRS+ (BIO-RAD).

Statistical analysis. The results are presented as the mean \pm standard deviation (SD) of three independent experiments. The data were analyzed using GraphPad Prism version 5. (GraphPad Software, San Diego, CA, USA). Differences were considered statistically significant when the $p$-value was less than 0.05 .

\section{Results}

Building a model for finding multi-target inhibitors by virtual screening. Because both PI3K and RAS signaling pathways have been reported to induce endocrine resistance in breast cancer $(53,54)$, we sought to identify small molecules for re-sensitizing breast cancer cells to endocrine therapies. To discover novel small molecules that inhibit ER $\alpha$, PI3K, and KRAS, we first conducted virtual screening 


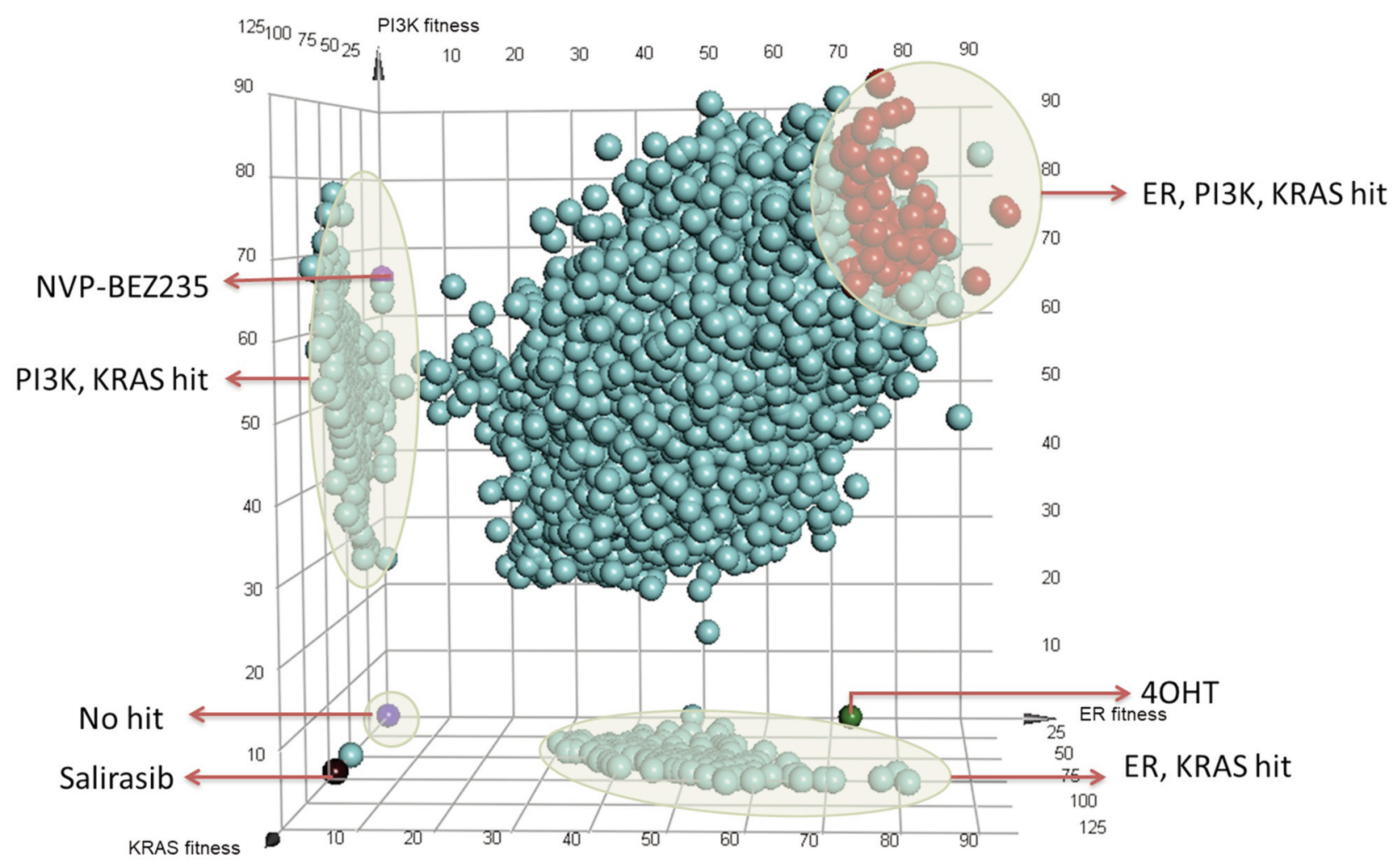

Figure 2. The principal triple-targeted fitness score analysis of compounds selected from the ZINC database. The cyan spheres falling within the grey circles are compounds with a reasonable score for interaction with the targets estrogen receptor alpha (ER $)$ ), phosphoinositide 3-kinase (PISK), and KRAS proto-oncogene, GTPase (KRAS). We utilized three well-established agents, 4-hydroxytamoxifen (4-OH; inhibitor of ER $\alpha$ ), NVPBEZ235 (inhibitor of PI3K) and salirasib (inhibitor of RAS), as references for scoring new compounds. The red spheres falling within the grey circle of at top right are novel triple-hit compounds which interact with all three targets.

using multiple natural product and drug libraries. We established a screening mode that combined the molecular docking of ER $\alpha, \mathrm{PI} 3 \mathrm{~K}$, and KRAS using GOLD5.1 software. Additionally, we used five compound libraries, namely, the Ambinter, Selleck, UEFS, SPECS, and TCM databases, with more than 40,000 small molecules being selected for inclusion in the screening mode (Figure 1). Well-known inhibitors of ER $\alpha$ (4-hydroxytamoxifen), PI3K (NVPBEZ235), and KRAS (salirasib) were used as positive standard for evaluating the GoldScores. As show in Figure 1 , the GoldScores of these inhibitors were 72.69, 65.40, and 68.73 , respectively. We then selected candidate compounds with values higher than those of these inhibitors. Using this approach, we found 812 hits for ER $\alpha, 3,478$ hits for PI3K, and 5,952 hits for KRAS. We further analyzed which of these compounds dual- or triple-inhibited ER $\alpha, \mathrm{PI} 3 \mathrm{~K}$, and KRAS, and identified 315 molecules that interacted with both ER $\alpha$ and PI3K, 382 molecules that interacted with both ER $\alpha$ and KRAS, 1645 molecules that interacted with both PI3K and KRAS, and 187 molecules that interacted with
$\mathrm{ER} \alpha, \mathrm{PI} 3 \mathrm{~K}$, and KRAS at the binding sites of the three targeted proteins (Figure 2). There were 10 compounds, namely, nicardipine hydrochloride (GoldScores for ER, PI3K and KRAS of $80.38,87.87$ and 80.34 , respectively), alexidine dihydrochloride $(74.89,68.46$ and 76.52), ( \pm )amethopterin (75.35, 73.69 and 81.67), chlorhexidine dihydrochloride (84.5, 72.27 and 69.06), cytidine 5'diphosphocholine sodium $(89.89,66.3$ and 106.72), kaempferol 3-O-glucuronide (73.35, 69.45 and 84.22), hyperoside $(84.79,67.63$ and 84.79), hamamelitannin (72.9, 75.92 and 76.99), glucocheirolin $(73.35,69.45$ and 84.22), and 1,3-dicaffeoylquinic acid (74.46, 67.63 and 84.79), that were selected from the 187 triple-hit compounds using knowledge-based selection.

To examine whether these triple-hit compounds exhibited biological activity against cancer cells upon EGF or $E_{2}$ stimulation, we assessed their effects on cell viability. EGF or $\mathrm{E}_{2}$ was deliberately added with the intention to increase $\mathrm{ER} \alpha-$ mediated and EGFR-mediated cell growth signaling. T47D were treated with select compounds at one-fold their half- 

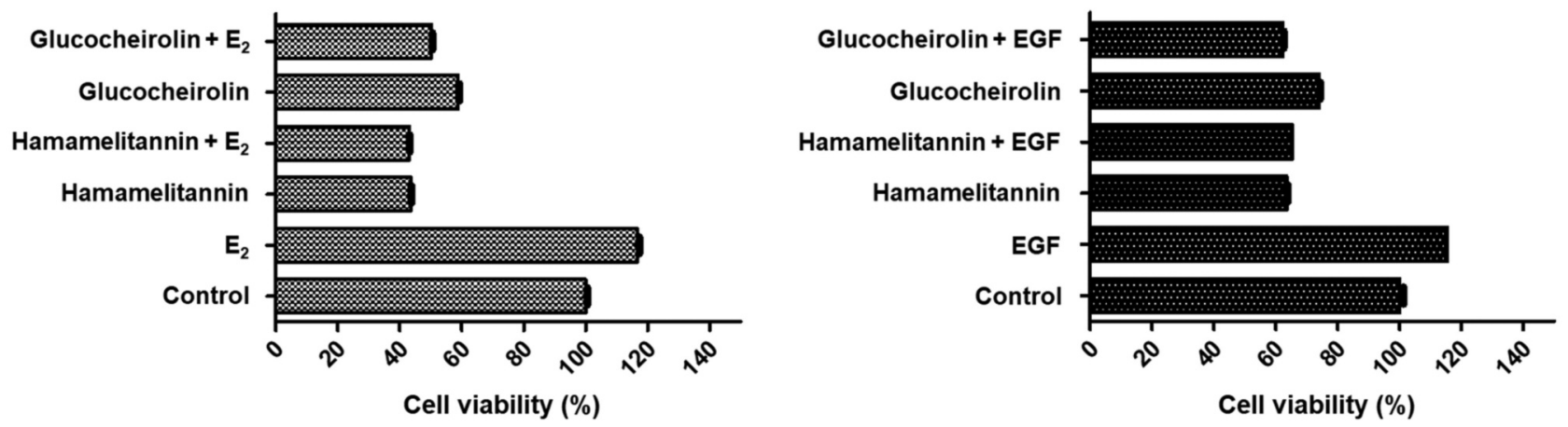

Figure 3. Cell viability assay of T47D breast cancer cell line after treatment with triple-hit compounds. Cells were treated only with hamamelitannin and glucocheirolin at 1-fold half-maximal inhibitory concentration and in combination with stimulation by $1 \mathrm{nM} 17 \mathrm{beta-estradiol}$ (E2) or $1 \mathrm{ng} / \mathrm{ml}$ epidermal growth factor (EGF), and then 3-(4,5-dimethylthiazol-2-yl)-2,5-diphenyltetrazolium bromide (MTT) reagent was added to monitor viable cells at $570 \mathrm{~nm}$. Data are the mean $\pm S D, n=3$.

maximal inhibitory concentration $\left(\mathrm{IC}_{50}\right)$ combined with/without $\mathrm{E}_{2}$ or EGF for 5 days, subsequently, the viability was assessed by MTT assay. As shown in Figure 3, we found that of the selected triple-hit compounds, hamamelitannin and glucocheirolin had inhibitory effects against $\mathrm{E}_{2}$ and EGFdriven proliferation, respectively, in the T47D breast cancer cell line. Treatment with $1 \mathrm{nM} \mathrm{E}_{2}$ or $1 \mathrm{ng} / \mathrm{ml}$ EGF significantly enhanced cell growth by up to $120 \%$ in comparison to non-stimulate treatment. Cells treated with hamamelitannin at the $\mathrm{IC}_{50}$ concentration suppressed $\mathrm{E}_{2}$ - and EGF-stimulated cell growth. Notably, glucocheirolin showed similar activity against $\mathrm{E}_{2}$ and EGF. Additionally, the mode of the compound-protein interactions showed that both hamamelitannin and glucocheirolin had a similar binding pattern even though these compounds had different types of chemical structure (Figure 4). Of particular note, both hamamelitannin and glucocheirolin interacted with Glu353 and $\operatorname{Arg} 394$ of $\mathrm{ER} \alpha$, which are critical to $\mathrm{E}_{2}-\mathrm{ER} \alpha$ interactions in the downstream signaling process (Figure 4). Moreover, hamamelitannin and glucocheirolin interacted with Tyr836 and Val851 of PI3K, which are AKT-binding sites (Figure 4).

Screening hits for multiple targets ER $, P I 3 K, K R A S$, and $S R C$. Apart from the identification of triple inhibitors of ER $\alpha$, PI3K and KRAS, HER2 is another target for breast cancer treatment. Recently, the importance of SRC in trastuzumab resistance has been emphasized (37-39), suggesting the urgent need for screening novel inhibitors for SRC inhibition. Thus, we further sought to screen triple-hits for inhibiting SRC, PI3K and KRAS. For this, we analyzed the GoldScores of the hit compounds shared between PI3K and KRAS (1,645 hits) for activity against SRC. The GoldScore of saracatinib, a positive standard for SRC protein, was 72.96. However, we extended the range of the search to all the docked compounds of SRC in order to increase the rate of discovery of triple inhibitors of PI3K, KRAS and SRC. In doing so, we found that only 119 molecules were common for inhibition of SRC, PI3K, and KRAS. Ultimately, we selected four targets in total, namely, $\mathrm{ER} \alpha, \mathrm{SRC}, \mathrm{PI} 3 \mathrm{~K}$ and KRAS, in order to discover new hit compounds. As shown in Figure 5, 187 hit compounds were shared between ER $\alpha, \mathrm{PI} 3 \mathrm{~K}$, and KRAS, and another 119 hits between SRC, PI3K, and KRAS. Therefore, in the knowledge-based selection, a total of 19 compounds, namely, glipizide (GoldScores for PI3K, KRAS and SRC of 71.14, 83.12 and 67.14 , respectively), sulfinpyrazone $(69.46,71.61$ and 60.99), atranorin (69.22, 70.28 and 63.97), cefamandole sodium $(67.19,80.28$ and 63.55$)$, benfotiamine $(72.34,93.94$ and 70.51), aminopterin (80.05, 79.49 and 73.43), mitoxantrone hydrochloride (72.88, 71.21 and 66.96), cefmetazole sodium $(68.24,72.04$ and 62.44$)$, bucladesine (66.4, 77.98 and 65.24), benzthiazide (69.85, 72.41 and 69.33), cephalosporin C sodium $(65.72,88.86$ and 60.01), rottlerin $(65.72,88.86$ and 67.97$)$, methyl prednisolone sodium succinate $(67.3,73.35$ and 30.3$)$, fumarprotocetraric acid (66.66, 75.58 and 62.57), riboflavin 5-phosphate sodium (80.64, 80.88 and 65.54), isochlorogenic acid C (66.15, 71.15 and 74.92), phthalylsulfathiazole (70.61, 74.06 and $71.9)$, pyritinol $(71.05,77.9$ and 68.18), and curcumin $(66.75,70.52$ and 63.09) were selected.

In-vitro validation of verified screened inhibitory compounds. Cell survival assay: After the verification of the screened compounds next, we examined whether the hit compounds of SRC, PI3K, and KRAS had the ability to inhibit cell viability upon EGF treatment. To assess their activities, cells were treated with $1 \mathrm{ng}$ EGF and then were co-treated with the selected hit compounds. Eighteen hit compounds were subjected to MTT assays. As shown in Figures 6 and 7, we found that eight of the hit compounds exhibited effects against 


\section{Hamamelitannin}
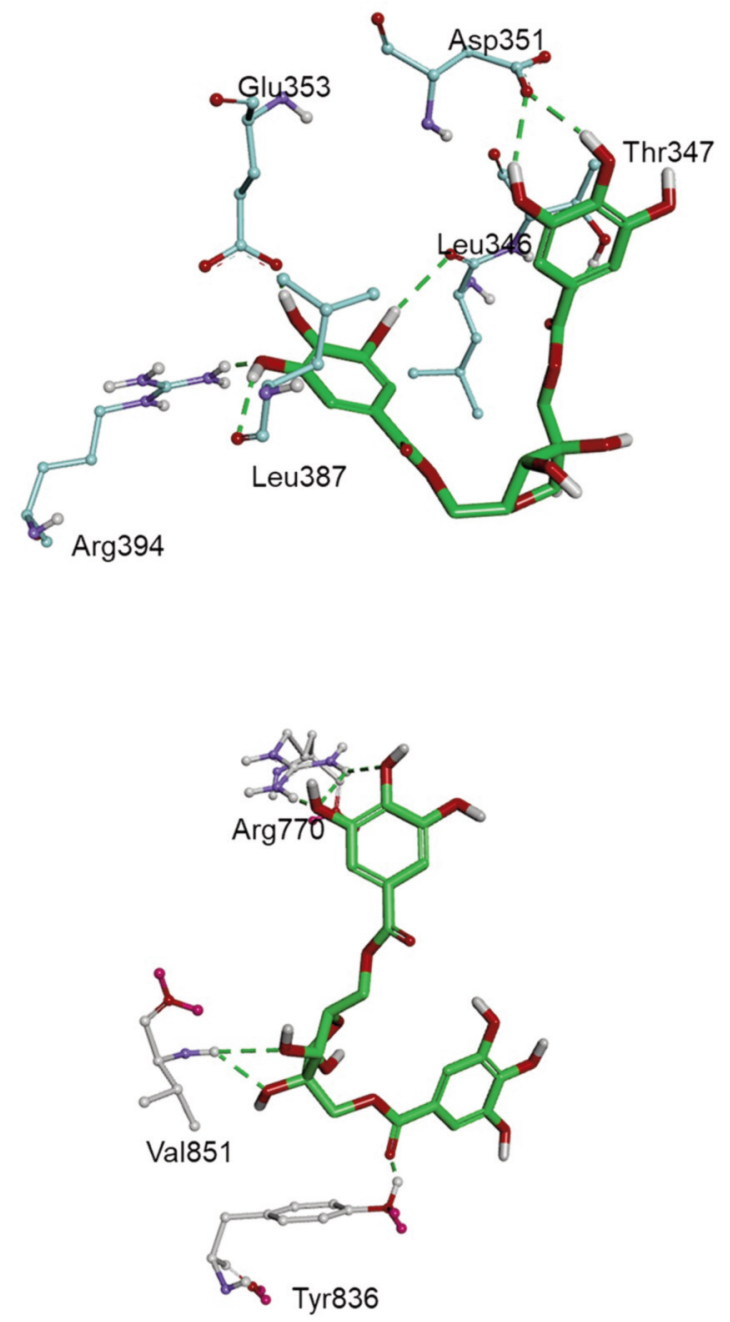

KRAS

\section{PI3K}

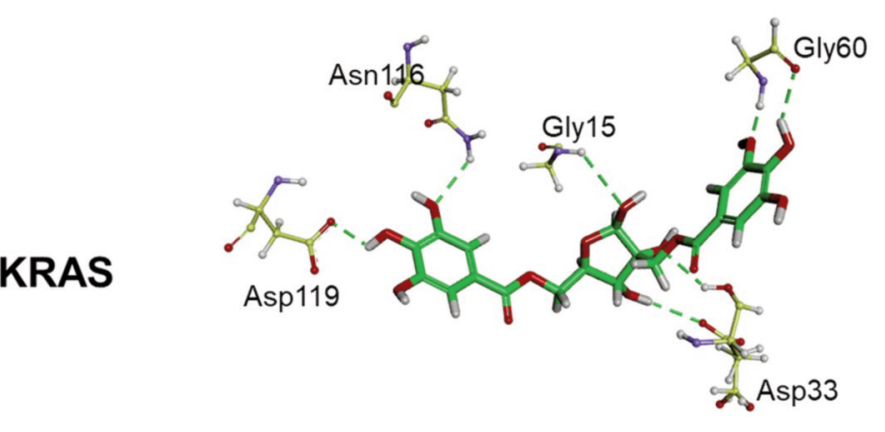

\section{Glucocheirolin}
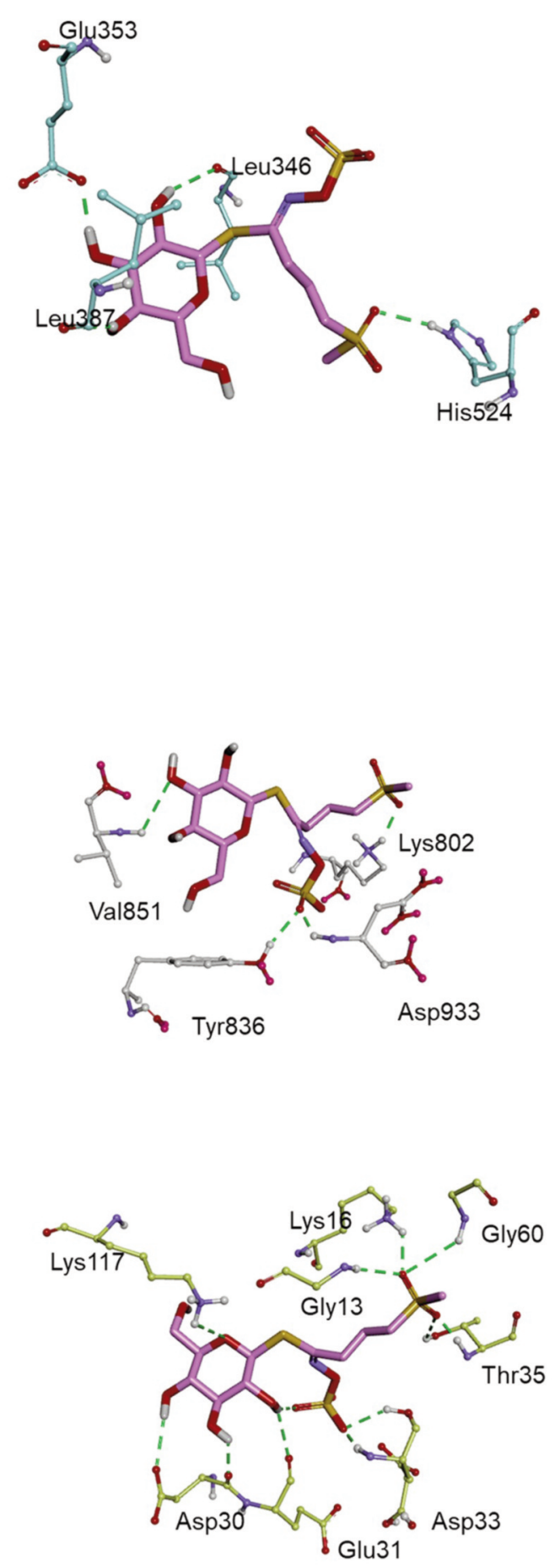

Figure 4. Typical stick structure model showing docking orientation and interaction of triple-hit compounds hamamelitannin and glucocheirolin with different residues of estrogen receptor alpha (ER $\alpha)$, phosphoinositide 3-kinase (PI3K), and KRAS proto-oncogene, GTPase (KRAS). Hamamelitannin (green stick) and glucocheirolin (pink stick) successfully docked into the ligand binding sites of ER $\alpha$ (cyan), PI3K (white) and KRAS (yellow), respectively. 


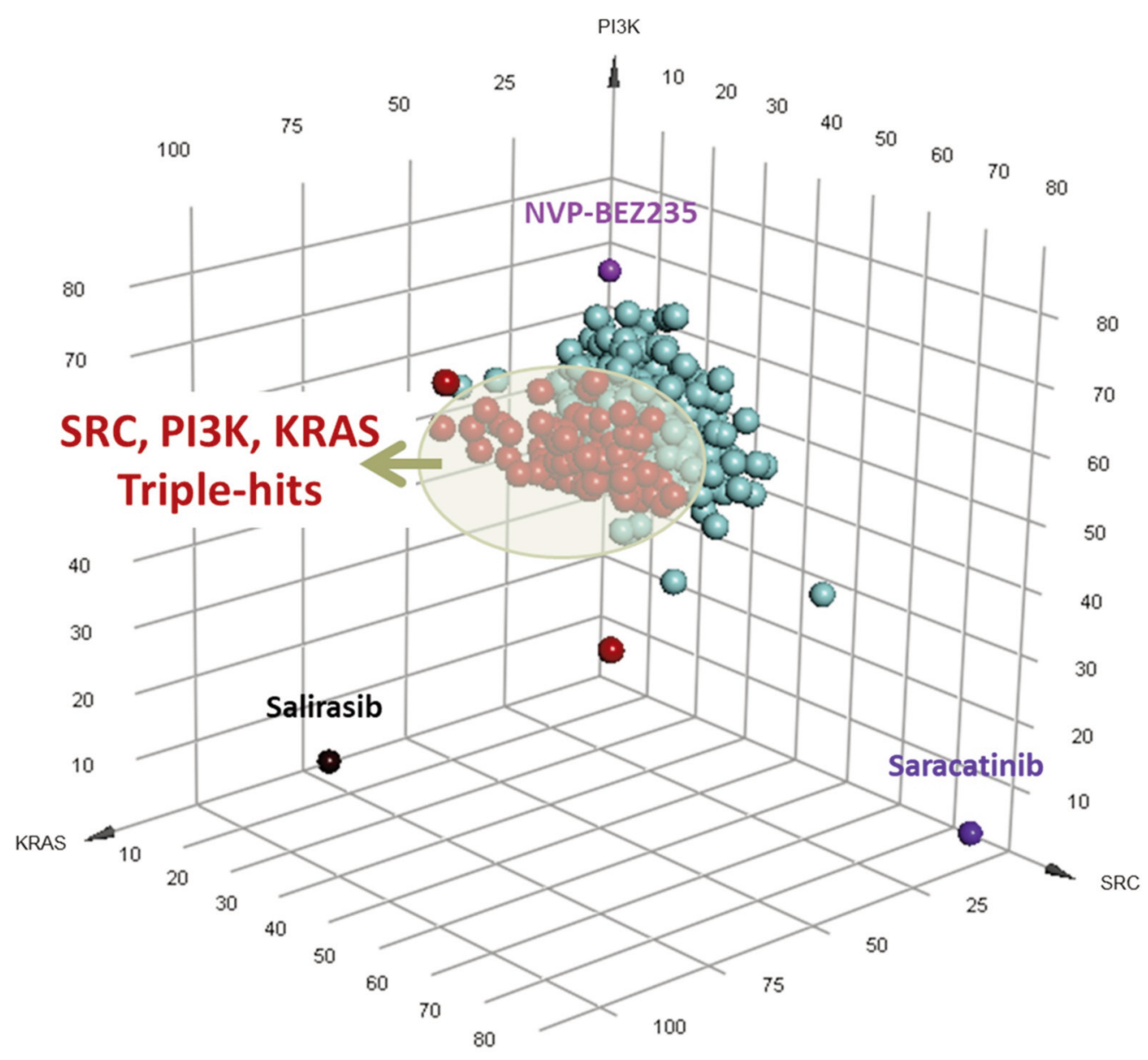

Figure 5. 3D Point chart representing the triple-targeted fitness score of docked compounds. The compounds (show as red spheres) from the database interact with three chosen target proteins phosphoinositide 3-kinase (PI3K), KRAS proto-oncogene (KRAS), and SRC proto-oncogene (SRC). The ligand docking scores were compared to those of three well-established agents NVP-BEZ235 (inhibitor of PI3K) salirasib (inhibitor of RAS), and saracatinib (inhibitor of SRC) to filter out other irrelevant compounds from the database.

EGF-stimulated cell proliferation. Specifically, atranorin, mitoxantrone, aminopterin, rottlerin, fumarprotocetraric acid, riboflavin 5-phosphate sodium, isochlorogenic acid $\mathrm{C}$ and curcumin reduced the viability of the cells by over $50 \%$. Interestingly, we found that atranorin and fumarprotocetraric acid, which are metabolites of the acetyl-polymalonyl pathway, both exist in lichen and showed similar activity profiles.

Immunoblot analysis: In order to investigate the effects of the hit compounds on the pathways of downstream signaling, we analyzed the status of phosphorylation of AKT and ERK upon treatment with the hit compounds under EGF stimulation. Cells were treated with EGF and then co-treated with the hit compounds at $0.25-, 0.5-, 1-$ and 2-fold $\mathrm{IC}_{50}$ values. As shown in Figures 8 and 9, treating the cells with EGF elevated their levels of p-AKT and p-ERK at 2 and 24 $h$, respectively. Our data indicated that atranorin and curcumin inhibited the phosphorylation of AKT at 0.25 - to 0.5 -fold $\mathrm{IC}_{50}$ values, but the signals were restored at 1- to 2fold $\mathrm{IC}_{50}$ values in the T47D cell line. Riboflavin 5phosphate inhibited the phosphorylation level of AKT and ERK at $24 \mathrm{~h}$ at more than 1 -fold $\mathrm{IC}_{50}$ values. Rottlerin inhibited the phosphorylation of AKT at low concentrations in the T47D and MCF-7 cells. Mitoxantrone not only inhibited the phosphorylation of AKT in both the MCF-7 and T47D cell lines but also inhibited the phosphorylation of ERK in MCF-7 cells at $2 \mathrm{~h}$. Aminopterin inhibited AKT and ERK in T47D cells at 0.25 - to 2-fold $\mathrm{IC}_{50}$ values and inhibited the phosphorylation of AKT in $\mathrm{MCF}-7$ cells upon EGF stimulation for $24 \mathrm{~h}$.

As shown in Figures 8 and 9, aminopterin was found to exhibit dual inhibition of the phosphorylation of AKT and 

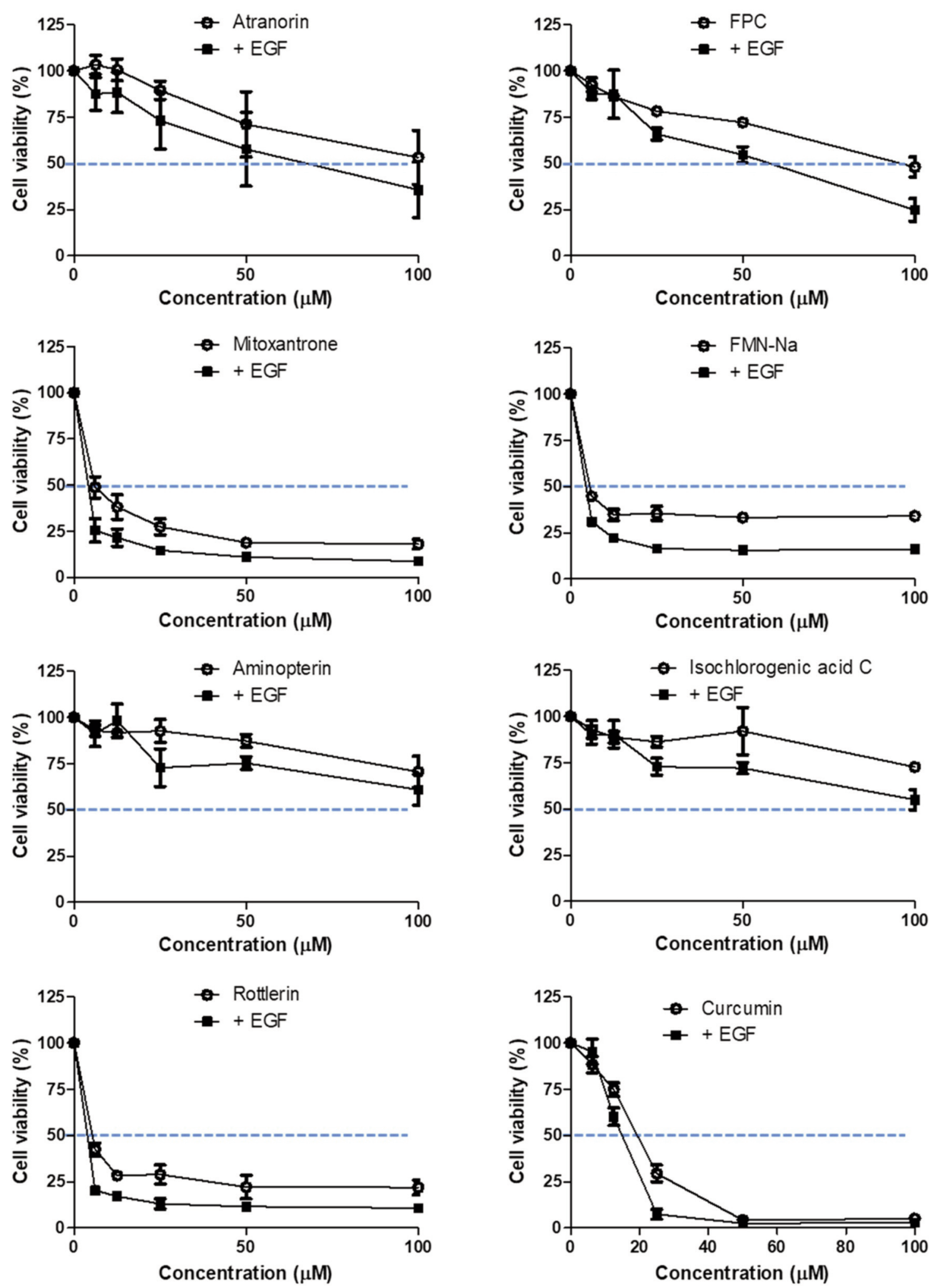

Figure 6. Cell survival analysis of the MCF-7 cell line upon treatment with potential hit compounds and the effect of co-treatment with $1 \mathrm{ng} / \mathrm{ml}$ epidermal growth factor (EGF). MCF-7 cells were treated $1 \mathrm{ng} / \mathrm{ml}$ EGF combined with 0, 6.25, 12.5, 25, 50, or $100 \mu \mathrm{M}$ of compounds [atranorin, fumarprotocetraric acid (FPC), mitoxantrone, riboflavin 5-phosphate sodium (FMN-Na), aminopterin, isochlorogenic acid C, rottlerin, and curcumin] for 5 days and viability of the cells was analyzed by employing 3-(4,5-dimethylthiazol-2-yl)-2,5-diphenyltetrazolium bromide reagent. Data are the mean $\pm S D, n=3$. 

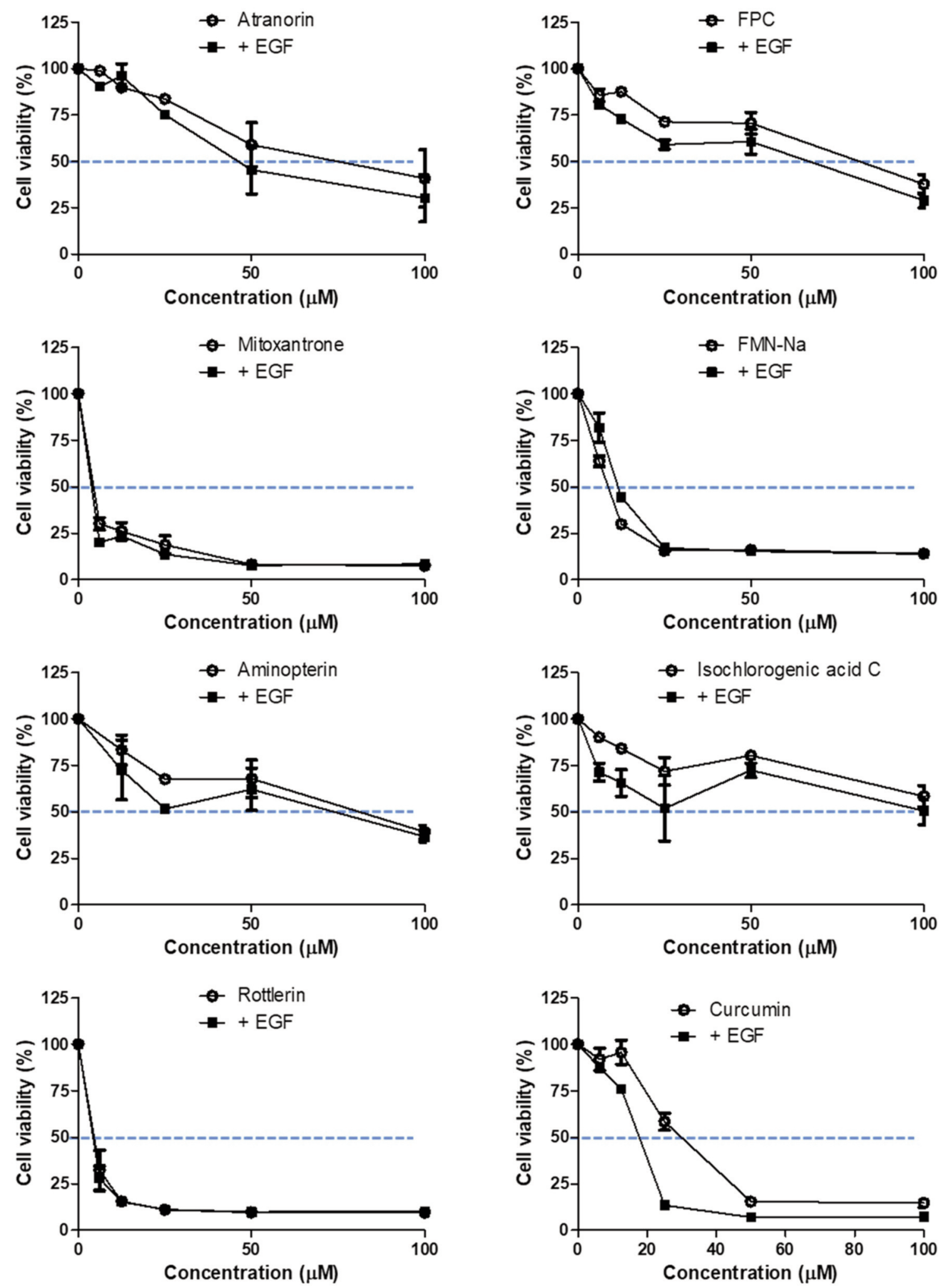

Figure 7.T47D breast cancer cell line was treated with candidate compounds (atranorin, FPC, mitoxantron, FMN-Na, aminopterin, isochlorogenic acid C, rottlerin, and curcumin) at 0, 6.25,12.5, 25, 50, $100 \mu \mathrm{M}$ with and without $1 \mathrm{ng} / \mathrm{ml}$ epidermal growth factor (EGF) for 5 days, then 3-(4,5dimethylthiazol-2-yl)-2,5-diphenyltetrazolium bromide reagent was added. Viability of cells in each well was determined at $570 \mathrm{~nm}$. Data are the mean $\pm S D, n=3$. 

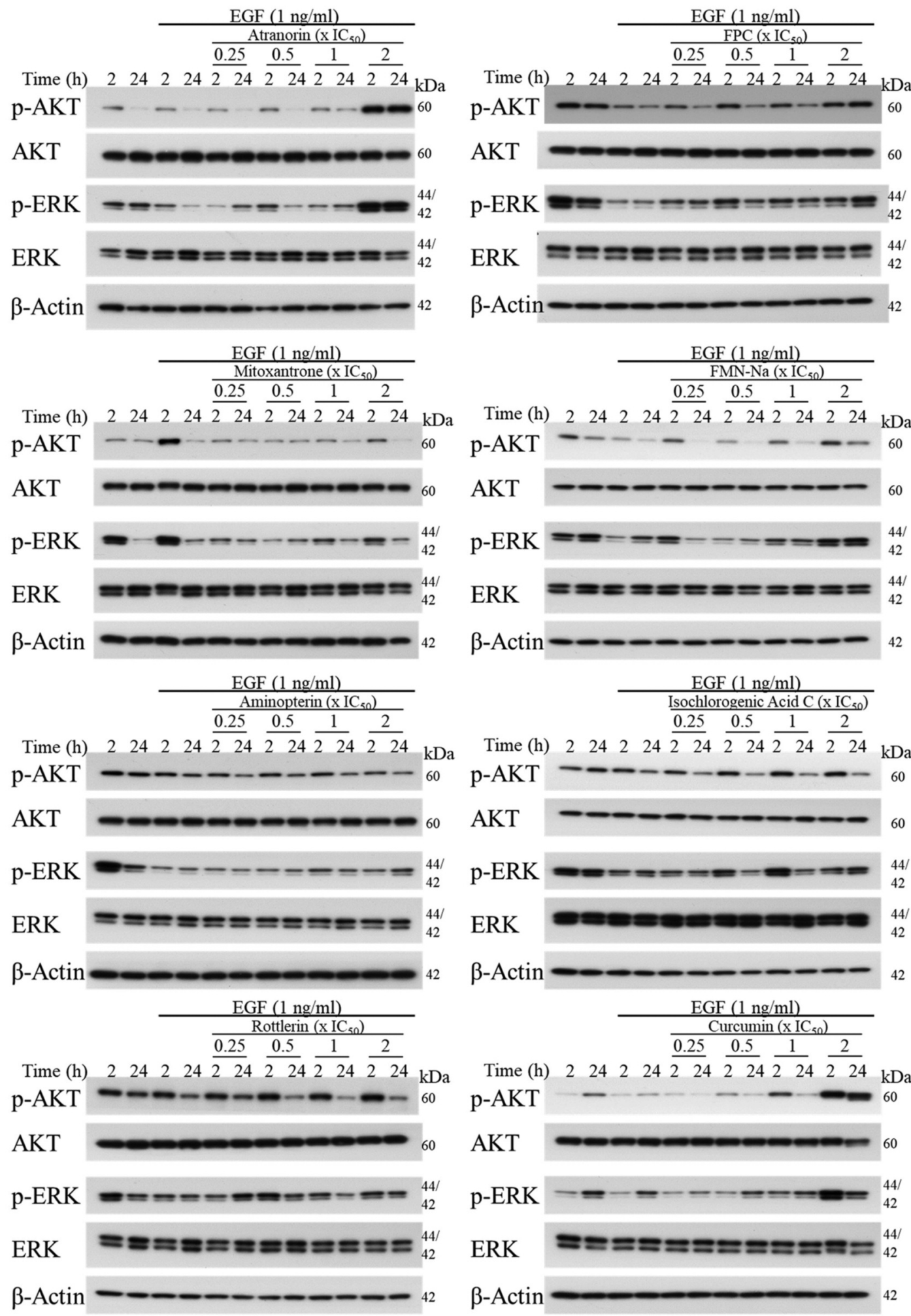

Time (h) $\begin{array}{llllllllllllllll}24 & 2 & 24 & \overline{224} & \overline{224} & \overline{224} & \overline{224} & \mathrm{kDa}\end{array}$ p-AKT - - - - - 60

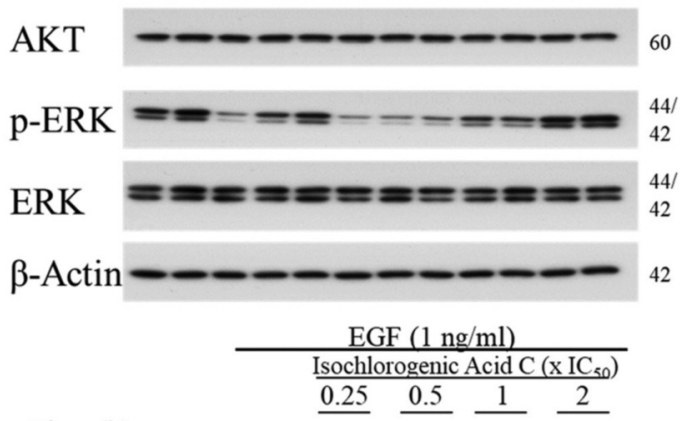

$\begin{array}{llllllllllllllll}\text { Time (h) } & 2 & 24 & 2 & 24 & \overline{2} 24 & \overline{2} 24 & \overline{224} & 224 & \mathrm{kDa}\end{array}$ p-AKT - - - - - - 60

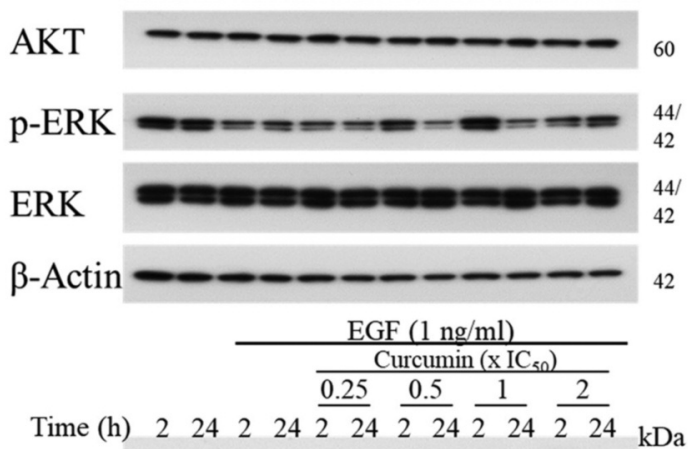
Time (h) $\begin{array}{lllllllllllllll}2 & 24 & 2 & 24 & 2 & 24 & 2 & 24 & 2 & 24 & 2 & 24 & \mathrm{kD}\end{array}$ p-AKT - - - 60

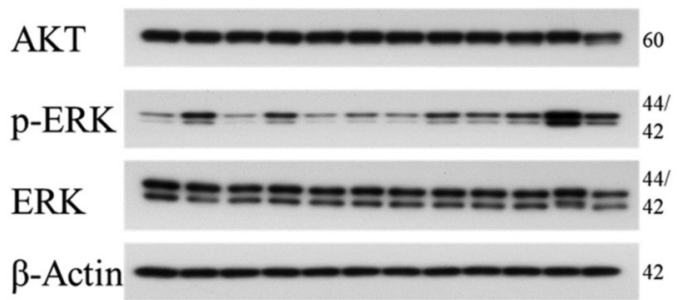

Figure 8. Critical signaling proteins involved in target inhibition by hit compounds in MCF-7 cells. MCF-7 cells were pre-treated with potential hit compounds at different fold of half-maximal inhibitory concentrations for 2 or $24 \mathrm{~h}$ in phenol-free medium comprising 5\% charcoal-stripped fetal bovine serum and co-treated with $1 \mathrm{ng} / \mathrm{ml}$ epidermal growth factor $(E G F)$. Cells were then harvested and the cell lysate was used to determine the change in expression pattern of phosphorylated and non-phosphorylated target proteins in serinelthreonine kinase 1 (AKT) and extracellular signalregulated kinase (ERK). 


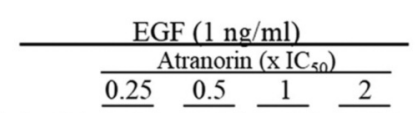

Time (h) $\begin{array}{llllllllllll}24 & 2 & 24 & \overline{224} & \overline{224} & \overline{224} & \overline{224} \\ \mathrm{kDa}\end{array}$ p-AKT - - - - - - -60

AKT

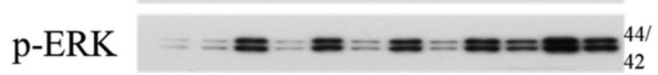

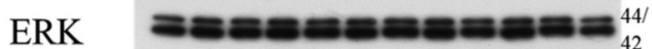

$\beta$-Actin

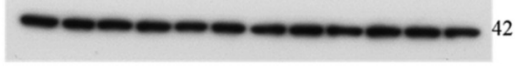

$\operatorname{EGF}(1 \mathrm{ng} / \mathrm{ml})$

Mitoxantrone $\left(\mathrm{x} \mathrm{IC}_{50}\right)$

Time (h) \begin{tabular}{llllllllll}
2 & 24 & 2 & 24 & $\frac{0.25}{224}$ & $\frac{0.5}{224}$ & $\frac{1}{224}$ & \multicolumn{2}{c}{24} & $\mathrm{kDa}$
\end{tabular} p-AKT -

$\mathrm{AKT}$ -

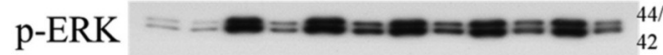

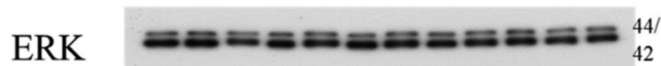

$\beta$-Actin con- 42

$\frac{\operatorname{EGF}(1 \mathrm{ng} / \mathrm{ml})}{\frac{\text { Aminopterin }\left(\mathrm{xIC} \mathrm{C}_{\mathrm{s0}}\right)}{0.25} \text { 0.5 } 1 \text { 2 }}$

Time (h) $\begin{array}{lllllllllll}24 & 2 & 24 & \overline{224} & \overline{224} & \overline{224} & \overline{224} & \mathrm{kDa}\end{array}$ p-AKT - - - - - - - 60

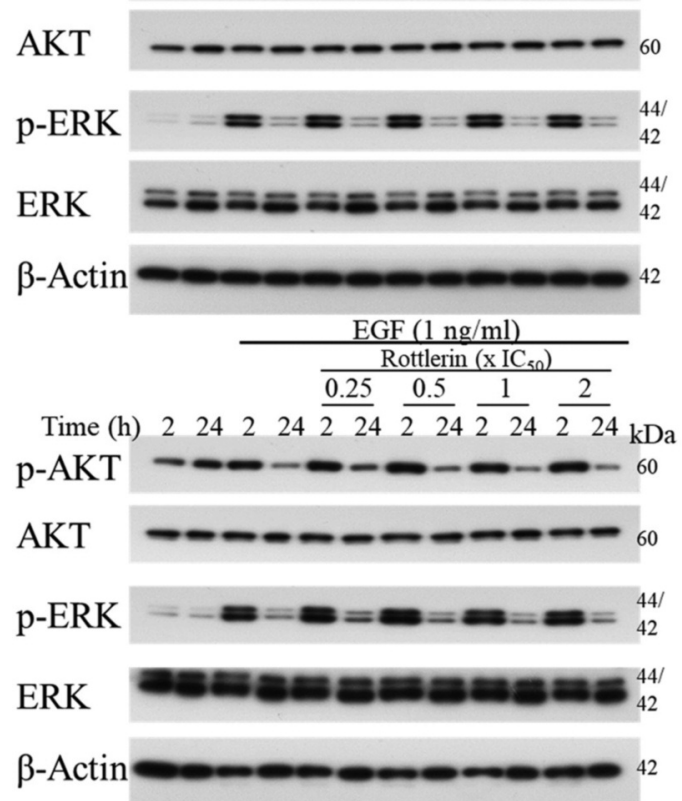

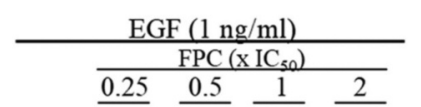

Time (h) $\begin{array}{llllllllllllll}24 & 2 & 24 & 224 & 224 & 224 & 224 & \mathrm{kDa}\end{array}$

p-AKT -

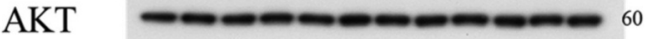

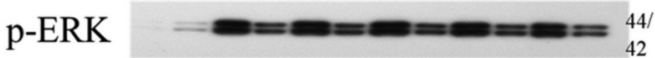

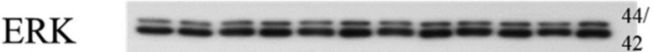

$\beta$-Actin - $-2-1-2-12$

$\operatorname{EGF}(1 \mathrm{ng} / \mathrm{ml})$

FMN-Na (xIC

$\begin{array}{lll}0.25 & 0.5 & 1\end{array}$

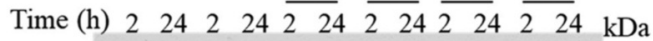
p-AKT - 60

AKT $=0-6=0$

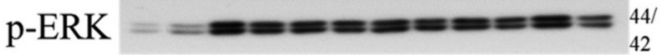

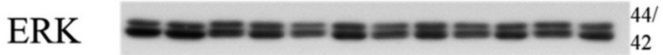

$\beta$-Actin $-2=0-2$

$\mathrm{EGF}(1 \mathrm{ng} / \mathrm{ml})$

Isochlorogenic Acid C (x IC 50$)$

$\begin{array}{llllllllll}0.25 & 0.5 & 1 & 2\end{array}$

Time (h) $2 \begin{array}{lllllllllllll}24 & 2 & 24 & 224 & 224 & 224 & 224 & \mathrm{kDa}\end{array}$

p-AKT - -

AKT $=-20-60$

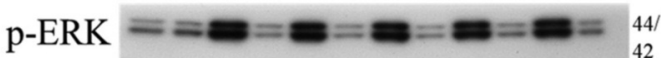

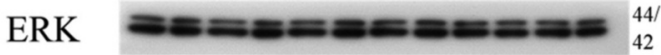

$\beta$-Actin - - - - - - - 42

$\operatorname{EGF}(1 \mathrm{ng} / \mathrm{ml})$

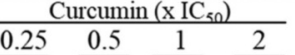

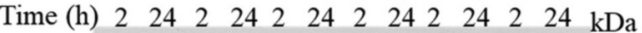

p-AKT - 60

$\mathrm{AKT}-2-1-100$

p-ERK $\quad-==-=-=-=-\begin{aligned} & 44 / \\ & 42\end{aligned}$

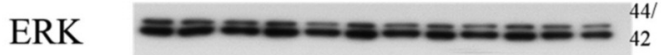

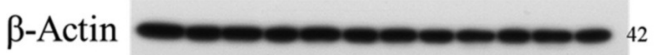

Figure 9. Critical signaling proteins involved in target inhibition by hit compounds in T47D cells. T47D cells were pre-treated with potential hit compounds at different fold of half-maximal inhibitory concentrations for 2 or $24 \mathrm{~h}$ in phenol-free medium comprising 5\% charcoal-stripped fetal bovine serum and stimulated with $1 \mathrm{ng} / \mathrm{ml}$ epidermal growth factor $(E G F)$. After the incubation, cells were then harvested and the cell lysate was used to monitor the changes in the expression pattern of phosphorylated and non-phosphorylated target proteins in serine/threonine kinase 1 (AKT) and extracellular signal-regulated kinase (ERK). 


\section{Folic acid}<smiles>Nc1nc2ncc(CNc3ccc(C(=O)N[C@@H](CCC(=O)O)C(=O)O)cc3)nc2c(=O)[nH]1</smiles>

Pemetrexed<smiles>Nc1nc2[nH]cc(CCc3ccc(C(=O)N[C@@H](CCC(=O)O)C(=O)O)cc3)c2c(=O)[nH]1</smiles>

Methotrexate<smiles>CN(Cc1cnc2nc(N)nc(N)c2n1)c1ccc(C(=O)N[C@@H](CCC(=O)O)C(=O)O)cc1</smiles>

\section{Aminopterin}

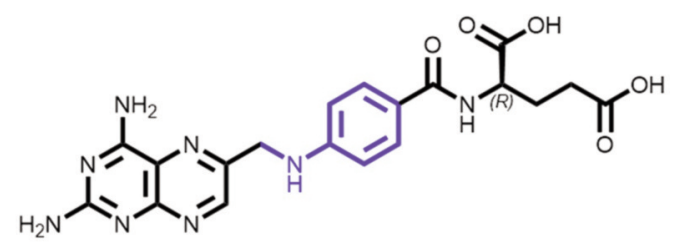

Figure 10. The molecular structure of folic acid, pemetrexed, methotrexate and aminopterin.

ERK at a wide range of concentrations. We found that the structure of aminopterin is similar to that of folic acid. Moreover, pemetrexed and methotrexate have structures like that of folic acid and can be developed as anticancer drugs by acting as folic acid antagonists (Figure 10). To examine whether pemetrexed and methotrexate have the same function as aminopterin, we used several breast cancer cell lines, MCF7, T47D, MDAMB-361, BT-474, and tamoxifen-resistant MCF-7 (MCF-7 R). For synchronizing all the cell lines at the same phosphorylation state at baseline, we starved these cell lines overnight and then treated them with a given drug for $1.5 \mathrm{~h}$ and then stimulated them with $1 \mathrm{nM} \mathrm{E}_{2}$ and $1 \mathrm{ng}$ EGF for $30 \mathrm{~min}$. Then, we determined the phosphorylation status of AKT and MEK, which are downstream signaling of PI3K and KRAS. In the BT474, T47D and MDAMB361 breast cancer cell lines, aminopterin inhibited the phosphorylation of AKT. Pemetrexed inhibited the phosphorylation of AKT and of MEK in the MDAMB-361 cell line (Figure 11). We used MCF-7 and the MCF-7 R cell lines to test these compounds. Our data indicate that pemetrexed inhibited the phosphorylation of AKT and MEK in the MCF-7 cell line. However, in the MCF-7 R cells, pemetrexed inhibited the phosphorylation of MEK, while aminopterin inhibited the phosphorylation of AKT (Figure 11).

\section{Discussion}

Structure-based virtual screening has proven to be a convenient and time-saving tool for lead-compound screening in drug development. In this study, we established a screening model that gave hits hamamelitannin and glucocheirolin, which we subsequently found effectively inhibited $\mathrm{E}_{2}$ and EGFstimulated proliferation of breast cancer cell lines (Figure 3). The docking data showed that hamamelitannin and glucocheirolin interacted with Glu353 on the $\mathrm{E}_{2}$-binding site of ER $\alpha$ and with Tyr836 and Val851 on the AKT-binding site of PI3K by forming hydrogen bonds. In previous studies, raloxifene and tamoxifen were also interactive with the same residue of Glu353 in ER $\alpha(34,55)$. In addition, NVP-BEZ235 was found to interact with Val851 in PI3K $(35,56)$. On the other hand, some reports showing that Tyr836 in PI3K was a key binding residue for active inhibitors (56, 57). Hamamelitannin and glucocheirolin acted on residues at the same position as these well-known inhibitors. This may imply that these small molecules also have the potential to inhibit the target protein. Previous studies reported that hamamelitannin and glucocheirolin also showed anti-proliferative effects on colon cancer $(58,59)$. Taken together, these data may suggest that hamamelitannin and glucocheirolin are able to desensitize cells to $\mathrm{E}_{2}$ or EGF stimulation cell growth through their ability to inhibit ER $\alpha$ and PI3K.

In the second screening, we found eight compounds which were able to counteract the stimulation of EGF treatment (Figures 6 and 7). One of them was aminopterin, which we found inhibited PI3K downstream signaling of phosphoAKT in the MCF-7 and T47D cell lines. The results presented in Figures 8, 9 and 11 suggest that aminopterin has the potential to act as a dual inhibitor of PI3K and KRAS. A phase II study showed that aminopterin led to the remission of acute lymphoblastic leukemia in children (60), while in another study it was effectively used against immune-related diseases such as rheumatoid arthritis (61). Our study is the very first of its kind, and revealed that aminopterin has the 


\section{Pemetrexed}
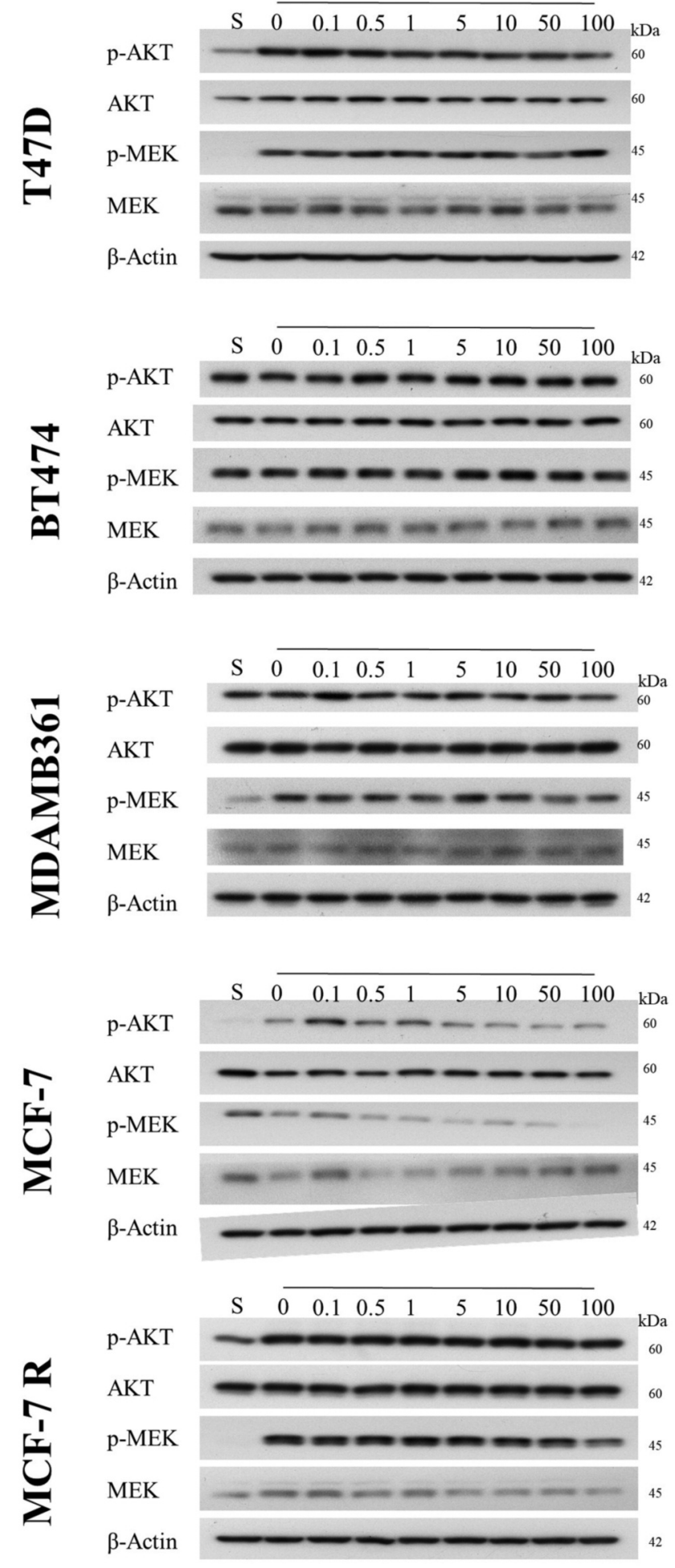

\section{Aminopterin}
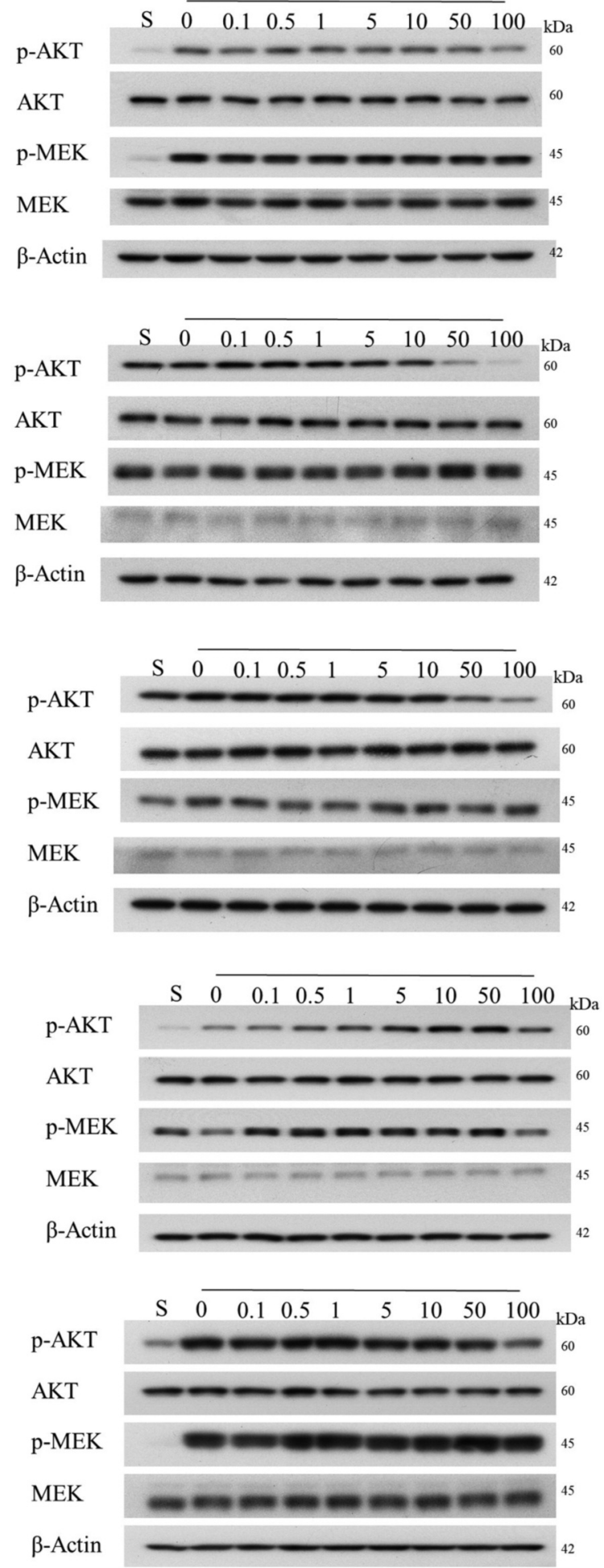

Figure 11. Dual inhibitor ability assay. Breast cancer cells were starved overnight (indicated as S) and then treated with pemetrexed and aminopterin at different concentrations for $2 \mathrm{~h}$ and stimulated by $1 \mathrm{nM} 17$ beta-estradiol and $1 \mathrm{ng} / \mathrm{ml}$ epidermal growth factor for $30 \mathrm{~min}$. After incubation, cells were harvested and analyzed for the expression pattern of phosphorylated and non-phosphorylated target proteins in serine/threonine kinase $1(A K T)$ and mitogen-activated protein kinase kinase (MEK) involved in downstream processing of the signal. 
ability to act as a dual inhibitor of PI3K and KRAS. This suggests, in turn, that aminopterin may be of benefit in patients with ER-positive breast cancer who be disease has become resistant to endocrine therapies.

Furthermore, we found that aminopterin exhibits a molecular structure (Figure 10) highly similar to that of folic acid. Aminopterin is an antifolate drug like the currently used drugs methotrexate and pemetrexed, both of which can inhibit onecarbon transfer reactions in nucleotide synthesis. In our study, we further found that aminopterin reduced the phosphorylation of $\mathrm{p}-\mathrm{AKT}$, even in the MCF-7 $\mathrm{R}$ cell line, and reduced the phosphorylation of $\mathrm{p}-\mathrm{MEK}$ in breast cancer cell lines under $\mathrm{E}_{2}$ and EGF stimulation. However, methotrexate, whose structure is most similar to that of aminopterin, did not inhibit phosphorylation in the downstream signaling of these target proteins. Comparing the structures of the four compounds, we assume that aminopterin may have better inhibitory ability due to the $R$ form structure on the right-side carbon chain, while pemetrexed provides partial inhibition of phosphorylation due to the nitrogen-containing heterocyclic on the left side (Figure 10). Of particular note is the fact that pemetrexed has reported benefit on recurrent, metastatic or advanced breast cancer in some clinical reports (62-64). Thus, it can be speculated that a structural modification of aminopterin might be instrumental in improving the current pemetrexed regimen.

Collectively, we identified four potential candidate compounds for targeting ER $\alpha$, PI3K, KRAS, and SRC using structure-based virtual screening. These findings may provide important insight into the development of new therapeutic approaches that target multiple RTKs-mediated activated pathways in breast cancer.

\section{Conflicts of Interest}

The Authors declare that the research was conducted in the absence of any commercial or financial relationships that could be construed as no conflict of interest.

\section{Authors' Contributions}

YHD and GYC acquired the data. WYC and JCY contributed to the concept and design of the project. YHD and JCY analyzed and interpreted the data. YHD and JCY performed the literature review and wrote the article. GYC, WCH, CHT and YCW revised the article.

\section{Acknowledgements}

The Authors are grateful to the National Center for High Performance Computing for providing computer time and related facilities. We also thank the Center for Resources, Research and Development of Kaohsiung Medical University for the ChemBio3D Ultra 11.0 technical support. This work was supported by Ministry of Sciences and Technology, Taiwan (MOST 109-2320-B-039-028; MOST 108-2622-B-039-005 -CC2), and China Medical University/ Hospital (CMU104-S-14-01; CMU108-MF-22; CMU108-MF-96).

\section{References}

1 Tao Z, Shi A, Lu C, Song T, Zhang Z and Zhao J: Breast cancer: Epidemiology and etiology. Cell Biochem Biophys 72(2): 333 338, 2015. PMID: 25543329. DOI: 10.1007/s 12013-014-0459-6

2 Gradishar WJ, Anderson BO, Balassanian R, Blair SL, Burstein HJ, Cyr A, Elias AD, Farrar WB, Forero A, Giordano SH, Goetz MP, Goldstein LJ, Isakoff SJ, Lyons J, Marcom PK, Mayer IA, McCormick B, Moran MS, O'Regan RM, Patel SA, Pierce LJ, Reed EC, Salerno KE, Schwartzberg LS, Sitapati A, Smith KL, Smith ML, Soliman H, Somlo G, Telli M, Ward JH, Shead DA and Kumar R: NCCN guidelines insights: Breast cancer, version 1.2017. J Natl Compr Canc Netw 15(4): 433-451, 2017. PMID: 28404755. DOI: $10.6004 /$ jnccn.2017.0044

3 Reinert $\mathrm{T}$ and Barrios $\mathrm{CH}$ : Optimal management of hormone receptor positive metastatic breast cancer in 2016. Ther Adv Med Oncol 7(6): 304-320, 2015. PMID: 26557899. DOI: $10.1177 / 1758834015608993$

4 Pan HC, Gray R, Braybrooke J, Davies C, Taylor C, McGale P, Peto R, Pritchard KI, Bergh J, Dowsett M, Hayes DF and EBCTCG: 20-Year risks of breast-cancer recurrence after stopping endocrine therapy at 5 years. N Engl J Med 377(19): 1836-1846, 2017. PMID: 29117498. DOI: 10.1056/NEJMoa1701830

5 Hsu MJ, Peng SF, Chueh FS, Tsai CH, Tsai FJ, Huang CY, Tang $\mathrm{CH}$, Yang JS, Hsu YM, Huang WW and Chung JG: Lupeol suppresses migration and invasion via p38/MAPK and $\mathrm{PI} 3 \mathrm{~K} / \mathrm{AKT}$ signaling pathways in human osteosarcoma $U-2$ OS cells. Biosci Biotechnol Biochem 83(9): 1729-1739, 2019. PMID: 31010399. DOI: 10.1080/09168451.2019.1606693

6 Fan W, Chang J and Fu P: Endocrine therapy resistance in breast cancer: Current status, possible mechanisms and overcoming strategies. Future Med Chem 7(12): 1511-1519, 2015. PMID: 26306654. DOI: $10.4155 / \mathrm{fmc} .15 .93$

7 Beeram M, Tan QTN, Tekmal RR, Russell D, Middleton A and Degraffenried LA: -induced endocrine therapy resistance is reversed by inhibition of mTOR signaling. Ann Oncol 18(8): 13231328, 2007. PMID: 17693645. DOI: 10.1093/annonc/mdm170

8 Osborne CK and Schiff R: Mechanisms of endocrine resistance in breast cancer. Annu Rev Med 62: 233-247, 2011. PMID: 20887199. DOI: 10.1146/annurev-med-070909-182917

9 Musgrove EA and Sutherland RL: Biological determinants of endocrine resistance in breast cancer. Nat Rev Cancer 9(9): 631643, 2009. PMID: 19701242. DOI: $10.1038 /$ nrc 2713

10 Osborne CK, Shou J, Massarweh S and Schiff R: Crosstalk between estrogen receptor and growth factor receptor pathways as a cause for endocrine therapy resistance in breast cancer. Clin Cancer Res 11(2): 865s-870s, 2005. PMID: 15701879.

11 Arpino G, Wiechmann L, Osborne CK and Schiff R: Crosstalk between the estrogen receptor and the HER tyrosine kinase receptor family: Molecular mechanism and clinical implications for endocrine therapy resistance. Endocr Rev 29(2): 217-233, 2008. PMID: 18216219. DOI: 10.1210/er.2006-0045

12 Baselga J, Campone M, Piccart M, Burris HA 3rd, Rugo HS, Sahmoud T, Noguchi S, Gnant M, Pritchard KI, Lebrun F, Beck JT, Ito Y, Yardley D, Deleu I, Perez A, Bachelot T, Vittori L, Xu Z, Mukhopadhyay P, Lebwohl D and Hortobagyi GN: Everolimus in postmenopausal hormonereceptor-positive advanced breast cancer. N Engl J Med 366(6): 520-529, 2012. PMID: 22149876. DOI: 10.1056/ NEJMoa1109653 
13 Bachelot T, Bourgier C, Cropet C, Ray-Coquard I, Ferrero JM, Freyer G, Abadie-Lacourtoisie S, Eymard JC, Debled M, Spaëth D, Legouffe E, Allouache D, El Kouri C and Pujade-Lauraine E: Randomized phase II trial of everolimus in combination with tamoxifen in patients with hormone receptor-positive, human epidermal growth factor receptor 2-negative metastatic breast cancer with prior exposure to aromatase inhibitors: A GINECO study. J Clin Oncol 30(22): 2718-2724, 2012. PMID: 22565002. DOI: $10.1200 / \mathrm{JCO} .2011 .39 .0708$

14 Schmid P, Pinder SE, Wheatley D, Macaskill J, Zammit C, Hu J, Price R, Bundred N, Hadad S and Shia A, Sarker SJ, Lim L, Gazinska P, Woodman N, Korbie D, Trau M, Mainwaring P, Gendreau S, Lackner MR, Derynck M, Wilson TR, Butler H, Earl G, Parker P, Purushotham A and Thompson A: Phase II randomized preoperative window-of-opportunity study of the PI3K inhibitor pictilisib plus anastrozole compared with anastrozole alone in patients with estrogen receptor-positive breast cancer. J Clin Oncol 34(17): 1987, 2016. PMID: 26976426. DOI: 10.1200/JCO.2015.63.9179

15 Turner NC, Neven P, Loibl S and Andre F: Advances in the treatment of advanced oestrogen-receptor-positive breast cancer. Lancet 389(10087): 2403-2414, 2017. PMID: 27939057. DOI: 10.1016/S0140-6736(16)32419-9

16 Patnaik A, Rosen LS, Tolaney SM, Tolcher AW, Goldman JW, Gandhi L, Papadopoulos KP, Beeram M, Rasco DW, Hilton JF, Nasir A, Beckmann RP, Schade AE, Fulford AD, Nguyen TS, Martinez R, Kulanthaivel P, Li LQ, Frenzel M, Cronier DM, Chan EM, Flaherty KT, Wen PY and Shapiro GI: Efficacy and safety of abemaciclib, an inhibitor of CDK4 and CDK6, for patients with breast cancer, non-small cell lung cancer, and other solid tumors. Cancer Discov 6(7): 740-753, 2016. PMID: 27217383. DOI: 10.1158/2159-8290.CD-16-0095

17 Shoichet BK: Virtual screening of chemical libraries. Nature 432(7019): 862-865, 2004. PMID: 15602552. DOI: 10.1038/ nature03197

18 Walters WP, Stahl MT and Murcko MA: Virtual screening - an overview. Drug Discov Today 3(4): 160-178, 1998. DOI: 10.1016/S1359-6446(97)01163-X

19 Bajorath J: Integration of virtual and high-throughput screening. Nat Rev Drug Discov 1(11): 882-894, 2002. PMID: 12415248. DOI: $10.1038 / \mathrm{nrd} 941$

20 Lyne PD: Structure-based virtual screening: An overview. Drug Discov Today 7(20): 1047-1055, 2002. PMID: 12546894. DOI: 10.1016/s1359-6446(02)02483-2

21 Willett P: Similarity-based virtual screening using 2D fingerprints. Drug Discov Today 11(23-24): 1046-1053, 2006. PMID: 17129822. DOI: 10.1016/j.drudis.2006.10.005

22 Butti R, Das S, Gunasekaran VP, Yadav AS, Kumar D and Kundu GC: Receptor tyrosine kinases (RTKs) in breast cancer: Signaling, therapeutic implications and challenges. Mol Cancer 17(1): 34, 2018. PMID: 29455658. DOI: 10.1186/s12943-018-0797-x

23 Boulay A, Rudloff J, Ye J, Zumstein-Mecker S, O’Reilly T, Evans DB, Chen S and Lane HA: Dual inhibition of mTOR and estrogen receptor signaling in vitro induces cell death in models of breast cancer. Clin Cancer Res 11(14): 5319-5328, 2005. PMID: 16033851. DOI: 10.1158/1078-0432.CCR-04-2402

24 Santarpia L, Qi Y, Stemke-Hale K, Wang B, Young EJ, Booser DJ, Holmes FA, O'Shaughnessy J, Hellerstedt B, Pippen J, Vidaurre T, Gomez H, Valero V, Hortobagyi GN, Symmans WF, Bottai G, Di Leo A, Gonzalez-Angulo AM and Pusztai L:
Mutation profiling identifies numerous rare drug targets and distinct mutation patterns in different clinical subtypes of breast cancers. Breast Cancer Res Treat 134(1): 333-343, 2012. PMID: 22538770. DOI: $10.1007 /$ s10549-012-2035-3

25 Ellis MJ, Ding L, Shen D, Luo J, Suman VJ, Wallis JW, Van Tine BA, Hoog J, Goiffon RJ, Goldstein TC, Ng S, Lin L, Crowder R, Snider J, Ballman K, Weber J, Chen K, Koboldt DC, Kandoth C, Schierding WS, McMichael JF, Miller CA, Lu C, Harris CC, McLellan MD, Wendl MC, DeSchryver K, Allred DC, Esserman L, Unzeitig G, Margenthaler J, Babiera GV, Marcom PK, Guenther JM, Leitch M, Hunt K, Olson J, Tao Y, Maher CA, Fulton LL, Fulton RS, Harrison M, Oberkfell B, Du F, Demeter R, Vickery TL, Elhammali A, Piwnica-Worms H, McDonald S, Watson M, Dooling DJ, Ota D, Chang LW, Bose R, Ley TJ, Piwnica-Worms D, Stuart JM, Wilson RK and Mardis ER: Whole-genome analysis informs breast cancer response to aromatase inhibition. Nature 486(7403): 353-360, 2012. PMID: 22722193. DOI: $10.1038 /$ nature 11143

26 Cancer Genome Atlas Network: Comprehensive molecular portraits of human breast tumours. Nature 490(7418): 61, 2012. PMID: 23000897. DOI: $10.1038 /$ nature 11412

27 Formisano L, Nappi L, Rosa R, Marciano R, D’Amato C, D'Amato V, Damiano V, Raimondo L, Iommelli F, Scorziello A, Troncone G, Veneziani B, Parsons SJ, De Placido S and Bianco $\mathrm{R}$ : Epidermal growth factor-receptor activation modulates SRCdependent resistance to lapatinib in breast cancer models. Breast Cancer Res 16(3): R45, 2014. PMID: 24887236. DOI: 10.1186/ bcr3650

28 Vallabhaneni S, Nair BC, Cortez V, Challa R, Chakravarty D, Tekmal RR and Vadlamudi RK: Significance of ER-SRC axis in hormonal therapy resistance. Breast Cancer Res Treat 130(2): 377385, 2011. PMID: 21184269. DOI: 10.1007/s10549-010-1312-2

29 Finn RS, Crown JP, Lang I, Boer K, Bondarenko IM, Kulyk SO, Ettl J, Patel R, Pinter T, Schmidt M, Shparyk YV, Thummala AR, Voytko NL, Huang X, Kim ST, Randolph SS and Slamon DJ: Abstract CT101: Final results of a randomized phase II study of PD 0332991, a cyclin-dependent kinase (CDK)-4/6 inhibitor, in combination with letrozole $v s$. letrozole alone for first-line treatment of ER+/HER2-advanced breast cancer (PALOMA-1; TRIO-18). 2014, AACR. Cancer Res 74(19 Suppl): Abstract nr CT101, 2014. DOI: 10.1158/15387445.AM2014-CT101

30 Johnston SR, Basik M, Hegg R, Lausoontornsiri W, Grzeda L, Dreosti MC, Ghiorghiu S, Mann H, Landers D, Stuart M and Cristofanilli M: Phase II randomized study of the EGFR, HER2, HER3 signaling inhibitor AZD8931 in combination with anastrozole (A) in women with endocrine therapy (ET) naive advanced breast cancer (MINT). J Clin Oncol 31(15): Abstract 531, 2013. DOI: 10.1200/jco.2013.31.15_suppl.531

31 Cristofanilli M, Turner NC, Bondarenko I, Ro J, Im S-A, Masuda N, Colleoni M, DeMichele A, Loi S and Verma SJTLO: Fulvestrant plus palbociclib versus fulvestrant plus placebo for treatment of hormone-receptor-positive, HER2-negative metastatic breast cancer that progressed on previous endocrine therapy (PALOMA-3): Final analysis of the multicentre, doubleblind, phase 3 randomised controlled trial. Lancet Oncol 17(4): 425-439, 2016. PMID: 26947331. DOI: 10.1016/S14702045(15)00613-0

32 Baselga J, van Dam PA, Greil R, Gardner H, Bandaru R, Molloy B, Steinseifer J, Phillips P, Dixon JM and Rugo HS: Improved 
clinical and cell cycle response with an mTOR inhibitor, daily oral RAD001 (everolimus) plus letrozole versus placebo plus letrozole in a randomized phase II neoadjuvant trial in $E R+$ breast cancer. J Clin Oncol 26(15): 530-530, 2008. PMID: 27948404. DOI: $10.1200 /$ jco.2008.26.15_suppl.530

33 Irwin JJ, Sterling T, Mysinger MM, Bolstad ES and Coleman RG: Zinc: A free tool to discover chemistry for biology. J Chem Inf Model 52(7): 1757-1768, 2012. PMID: 22587354. DOI: $10.1021 / \mathrm{ci} 3001277$

34 Shiau AK, Barstad D, Loria PM, Cheng L, Kushner PJ, Agard DA and Greene GL: The structural basis of estrogen receptor/coactivator recognition and the antagonism of this interaction by tamoxifen. Cell 95(7): 927-937, 1998. PMID: 9875847. DOI: $10.1016 /$ S0092-8674(00)81717-1

35 Mandelker D, Gabelli SB, Schmidt-Kittler O, Zhu J, Cheong I, Huang CH, Kinzler KW, Vogelstein B and Amzel LM: A frequent kinase domain mutation that changes the interaction between PI3Kalpha and the membrane. Proc Natl Acad Sci USA 106(40): 16996-17001, 2009. PMID: 19805105. DOI: 10.1073/pnas.0908444106

36 Tong Y, Tempel W, Shen L, Arrowsmith CH, Edwards AM, Sundstrom M, Weigelt J, Bochkarev A, Park H and Structural Genomics Consortium (SGC): Human KRAS in complex with a GTP analogue. PDB ID: 3GFT, 2019. DOI: 10.2210/pdb3gft/pdb

37 Hennequin LF, Allen J, Breed J, Curwen J, Fennell M, Green TP, Lambert-van der Brempt C, Morgentin R, Norman RA, Olivier A, Otterbein L, Ple PA, Warin N and Costello G: $N$-(5-Chloro1,3-benzodioxol-4-yl)-7-[2-(4-methylpiperazin-1-yl)ethoxy]-5(tetrahydro-2h-pyran-4-yloxy)quinazolin-4-amine, a novel, highly selective, orally available, dual-specific c-SRC/ABL kinase inhibitor. J Med Chem 49(22): 6465-6488, 2006. PMID: 17064066. DOI: 10.1021/jm060434q

38 Berman HM, Westbrook J, Feng Z, Gilliland G, Bhat TN, Weissig H, Shindyalov IN and Bourne PE: The protein data bank. Nucleic Acids Res 28(1): 235-242, 2000. PMID: 10592235. DOI: 10.1093/nar/28.1.235.

39 Visualizer, DS, Discovery studio Visualizer 3.5., 2017.

40 Jones $\mathrm{G}$, Willett $\mathrm{P}$ and Glen RC: Molecular recognition of receptor-sites using a genetic algorithm with a description of desolvation. J Mol Biol 245(1): 43-53, 1995. PMID: 7823319. DOI: Doi 10.1016/S0022-2836(95)80037-9

41 Jones G, Willett P, Glen RC, Leach AR and Taylor R: Development and validation of a genetic algorithm for flexible docking. J Mol Biol 267(3): 727-748, 1997. PMID: 9126849. DOI: $10.1006 /$ jmbi.1996.0897

42 Verdonk ML, Cole JC, Hartshorn MJ, Murray CW and Taylor RD: Improved protein-ligand docking using GOLD. Proteins 52(4): 609-623, 2003. PMID: 12910460. DOI: 10.1002/prot.10465

43 Hendlich M, Rippmann F and Barnickel G: Ligsite: Automatic and efficient detection of potential small molecule-binding sites in proteins. J Mol Graph Model 15(6): 359-363, 389, 1997. PMID: 9704298. DOI: 10.1016/s1093-3263(98)00002-3

44 Ali S and Coombes RC: Estrogen receptor alpha in human breast cancer: Occurrence and significance. J Mammary Gland Biol Neoplasia 5(3): 271-281, 2000. PMID: 14973389. DOI: 10.1023/ a: 1009594727358

45 Serra V, Markman B, Scaltriti M, Eichhorn PJ, Valero V, Guzman M, Botero ML, Llonch E, Atzori F, Di Cosimo S, Maira M, Garcia-Echeverria C, Parra JL, Arribas J and Baselga J: Nvpbez235, a dual PI3K/MTOR inhibitor, prevents PI3K signaling and inhibits the growth of cancer cells with activating PI3K mutations. Cancer Res 68(19): 8022-8030, 2008. PMID: 18829560. DOI: $10.1158 / 0008-5472 . C A N-08-1385$

46 Rotblat B, Ehrlich M, Haklai R and Kloog Y: The RAS inhibitor farnesylthiosalicylic acid (Salirasib) disrupts the spatiotemporal localization of active RAS: A potential treatment for cancer. Methods Enzymol 439: 467-489, 2008. PMID: 18374183. DOI: 10.1016/S0076-6879(07)00432-6

47 Wang L, Yu X, Dong J, Meng Y, Yang Y, Wang H, Wang C, Zhang Y, Zhao Y, Zhao J, Wang H, Lu C and Li B: Combined $S R C$ inhibitor saracatinib and anti-ERBB2 antibody H2-18 produces a synergistic antitumor effect on trastuzumab-resistant breast cancer. Biochem Biophys Res Commun 479(3): 563-570, 2016. PMID: 27666484. DOI: 10.1016/j.bbrc.2016.09.111

48 You YH, Lin YF, Nirosha B, Chang HT and Huang YF: Polydopamine-coated gold nanostar for combined antitumor and antiangiogenic therapy in multidrug-resistant breast cancer. Nanotheranostics 3(3): 266-283, 2019. PMID: 31263658. DOI: $10.7150 /$ ntno. 36842

49 Lee HP, Chen PC, Wang SW, Fong YC, Tsai CH, Tsai FJ, Chung JG, Huang CY, Yang JS, Hsu YM, Li TM and Tang CH: Plumbagin suppresses endothelial progenitor cell-related angiogenesis in vitro and in vivo. J Funct Foods 52: 537-544, 2019. DOI: $10.1016 /$ j.jff.2018.11.040

50 Chen C-C, Chueh F-S, Peng S-F, Huang W-W, Tsai C-H, Tsai F-J, Huang C-Y, Tang C-H, Yang J-S, Hsu Y-MJB, biotechnology, and biochemistry: Cantharidin decreased viable cell number in human osteosarcoma U-2 OS cells through G2/M phase arrest and induction of cell apoptosis. Biotechnol Biochem 83(10): 1912-1923, 2019. PMID: 31187696. DOI: 10.1080/09168451.2019.1627182

51 Liu S-C, Tsai C-H, Wu T-Y, Tsai C-H, Tsai F-J, Chung J-G, Huang C-Y, Yang J-S, Hsu Y-M, Yin M-C, Wu Y-C and Tang C$\mathrm{H}$ : Soya-cerebroside reduces IL-1 $\beta$-induced MMP-1 production in chondrocytes and inhibits cartilage degradation: Implications for the treatment of osteoarthritis. Food Agric Immunol 30(1): 620-632, 2019. DOI: 10.1080/09540105.2019.1611745

$52 \mathrm{Wu}$ KM, Hsu YM, Ying MC, Tsai FJ, Tsai CH, Chung JG, Yang JS, Tang CH, Cheng LY, Su PH, Viswanadha VP, Kuo WW and Huang CY: High-density lipoprotein ameliorates palmitic acidinduced lipotoxicity and oxidative dysfunction in $\mathrm{H} 9 \mathrm{c} 2$ cardiomyoblast cells via ROS suppression. Nutr Metab 16(1): 36, 2019. PMID: 31149020. DOI: 10.1186/s12986-019-0356-5

53 Ramaswamy B, Lu Y, Teng K-y, Nuovo G, Li X, Shapiro CL and Majumder SJCr: Hedgehog signaling is a novel therapeutic target in tamoxifen-resistant breast cancer aberrantly activated by PI3K/AKT pathway. Cancer Res 72(19): 5048-5059, 2012. PMID: 22875023. DOI: 10.1158/0008-5472.CAN-12-1248

54 Osborne CK and Schiff R: Growth factor receptor cross-talk with estrogen receptor as a mechanism for tamoxifen resistance in breast cancer. Breast 12(6): 362-367, 2003. PMID: 14659106. DOI: $10.1016 /$ S0960-9776(03)00137-1

55 Heldring N, Pawson T, McDonnell D, Treuter E, Gustafsson JA and Pike ACW: Structural insights into corepressor recognition by antagonist-bound estrogen receptors. J Biol Chem 282(14): 10449-10455, 2007. PMID: 17283072. DOI: 10.1074/jbc. M611424200

56 Sabbah DA, Hu J and Zhong HA: Advances in the development of class i phosphoinositide 3-kinase (PI3K) inhibitors. Curr Top Med Chem 16(13): 1413-1426, 2016. PMID: 26369826. DOI: $10.2174 / 1568026615666150915115823$ 
57 Sabbah DA, Simms NA, Brattain MG, Vennerstrom JL and Zhong H: Biological evaluation and docking studies of recently identified inhibitors of phosphoinositide-3-kinase. Bioorg Med Chem Lett 22(2): 876-880, 2012. PMID: 22212721. DOI: 10.1016/j.bmcl.2011.12.044

58 Sánchez-Tena S, Fernandez-Cachon ML, Carreras A, MateosMartín ML, Costoya N, Moyer MP, Nunez MJ, Torres JL and Cascante M: Hamamelitannin from witch hazel (Hamamelis virginiana) displays specific cytotoxic activity against colon cancer cells. J Nat Prod 75(1): 26-33, 2012. PMID: 22216935. DOI: $10.1021 / \mathrm{np} 200426 \mathrm{k}$

59 Hayes JD, Kelleher MO and Eggleston IM: The cancer chemopreventive actions of phytochemicals derived from glucosinolates. Eur J Nutr 47 Suppl 2(2): 73-88, 2008. PMID: 18458837. DOI: $10.1007 / \mathrm{s} 00394-008-2009-8$

60 Cole PD, Drachtman RA, Masterson M, Smith AK, Glod J, Zebala JA, Lisi S, Drapala DA and Kamen BA: Phase 2 b trial of aminopterin in multiagent therapy for children with newly diagnosed acute lymphoblastic leukemia. Cancer Chemother Pharmacol 62(1): 65-75, 2008. PMID: 17768625. DOI: 10.1007/s00280-007-0576-7

61 Gubner R, August S and Ginsberg V: Therapeutic suppression of tissue reactivity. 2. Effect of aminopterin in rheumatoid arthritis and psoriasis. Am J Med Sci 221(2): 176-182, 1951. PMID: 14799481.
62 Miles DW, Smith IE, Coleman RE, Calvert AH and Lind MJ: A phase II study of pemetrexed disodium (LY231514) in patients with locally recurrent or metastatic breast cancer. Eur J Cancer 37(11): 1366-1371, 2001. PMID: 11435066. DOI: 10.1016/ s0959-8049(01)00117-4

63 Garin A, Manikhas A, Biakhov M, Chezhin M, Ivanchenko T, Krejcy K, Karaseva V and Tjulandin S: A phase II study of pemetrexed and carboplatin in patients with locally advanced or metastatic breast cancer. Breast Cancer Res Treat 110(2): 309315, 2008. PMID: 17851759. DOI: 10.1007/s10549-007-9722-5

64 Gomez HL, Santillana SL, Vallejos CS, Velarde R, Sanchez J, Wang X, Bauer NL, Hockett RD, Chen VJ, Niyikiza C and Hanauske AR: A phase II trial of pemetrexed in advanced breast cancer: Clinical response and association with molecular target expression. Clin Cancer Res 12(3 Pt 1): 832-838, 2006. PMID: 16467096. DOI: 10.1158/1078-0432.CCR-05-0295

Received October 21, 2020

Revised November 21, 2020

Accepted November 24, 2020 